\title{
THE GENUS MILIUSA (ANNONACEAE) IN THE AUSTRO-MALESIAN AREA
}

\author{
J.B. MOLS \& P.J.A. KESSLER \\ Nationaal Herbarium Nederland, Universiteit Leiden branch, P.O. Box 9514, 2300 RA Leiden, \\ The Netherlands.E-mail: mols@nhn.leidenuniv.nl, kessler@nhn.leidenuniv.nl
}

\section{SUMMARY}

A taxonomic revision of the Austro-Malesian species of Miliusa Lesch. ex A.DC. (Annonaceae) is presented. Ten species can be recognised in the area, including one new species, Miliusa novoguineensis, described here. Most species are restricted to certain islands or geographic areas. Miliusa horsfieldii (Benn.) Pierre is the main exception as it is distributed from Hainan up to Queensland, Australia. Six of the ten species (except $M$. amplexicaulis Ridl., M. longipes King, M. macropoda Miq. and M. parviflora Ridl.) have a deciduous habit, and are largely restricted to areas with a monsoon climate. A key, based primarily on generative characters, and descriptions to the species are included.

Key words: Annonaceae, Miliusa, Flora Malesiana, Australia, revision.

\section{INTRODUCTION}

Annonaceae are a pantropical family of shrubs, trees and lianas. The family consists of about 130 genera and 2300 species. The largest number of genera and species are known from Asia (including Australia and the Pacific), with c. 60 and 1000, respectively. In comparison c. 40 genera and 800 species are recorded in America, while Africa holds c. 40 genera and 500 species.

Although the position of Annonaceae within the Angiosperms and order Magnoliales and its family circumscription is clear and undisputed (Keßler, 1993; Soltis et al., 2000; Qiu et al., 2000), the genera within the family are very difficult to define and not easily placed in 'natural groups'.

The relationships between the genera of tribe Miliuseae are subject of a phylogenetic study by the first author. All genera included, except the genus Miliusa, have been revised recently (for a review see Mols \& Keßler, in press). The revision of the Austro-Malesian species of Miliusa presented here will be used to complement the morphological dataset on the tribe Miliuseae for comparison with a currently assembled molecular dataset (Mols et al., in prep.) and also to use both datasets in a combined analysis.

\section{THE TRIBE MILIUSEAE}

The circumscription of the tribe Miliuseae has been based primarily on the presence of stamens without a protruding connective prolongation, the so-called miliusoid stamens (Hooker \& Thomson, 1855). Hooker \& Thomson used two names for the tribe. In the introduction and general classification of Annonaceae the tribe was named 
Saccopetaleae, while in the description of the tribes and genera the name Miliuseae is used instead. Miquel (1858) was the first to use the name Miliuseae exclusively and to designate Saccopetaleae as a synonym.

According to the most recent informal classification by Keßler (1993) Miliuseae consist of Alphonsea (30 species), Mezzettia Becc. (5 spp., this genus is doubtfully placed in the tribe), Mezzettiopsis Ridl. (= Orophea (Leonardía \& Keßler, 2001)), Miliusa (including Saccopetalum c. 35 spp.), Orophea Blume (50 spp.), Phoenicanthus Alston (2 spp.) and Platymitra Boerl. (2 spp.).

Even though the diagnostic character (miliusoid stamen) of the tribe is limited to this group of genera, the monophyly of the tribe has been disputed (Mols \& Keßler, in press). Preliminary analyses using molecular data support this view (Mols et al., in prep.). In analyses including a large number of genera throughout the family, Miliuseae appear polyphyletic with Mezzettia and Miliusa only distantly related to the clade including Alphonsea, Orophea and Platymitra.

\section{MILIUSA}

The genus Miliusa was described by De Candolle in 1832 with the species Miliusa leschenaultii A.DC. after a specimen collected by Leschenault de la Tour in 1823. The name Miliusa was given by Leschenault de la Tour in honour of the 'baron de Milius', a French marine officer and protector of botany in the French colonies and companion of Leschenault de la Tour on his voyage on the Le Géographe (1800-1804) in the Pacific (De Candolle, 1832; Backer, 2000). De Candolle described this material as a new genus because the specimens only had three petals, which had a saccate base and were united. These and other characters mentioned in the introduction and description do not fit the general perception of the species or even the genus based on all material available. When checking the type specimen (DC-G) and comparing it with additional material from the same area we concluded that the type is genetically aberrant (for more details see note 2 of the generic description).

Up to now the type species has been referred to as Miliusa indica, but we conclude that the correct name should be $M$. leschenaultii (see also note 1 of the generic description in this article).

The genus Miliusa presently also includes the former genera Saccopetalum Benn. and Hyalostemma Wall. Hyalostemma was established by Wallich (1832) when he transferred Uvaria dioica (as 'dioeca') Roxb. to a new genus Hyalostemma, but he named the type species Hyalostemma roxburghiana instead of $H$. dioica. When Hooker \& Thomson (1855) transferred Hyalostemma to Miliusa the first name was used and they named the species $M$. roxburghiana, which must be considered a superfluous name. Panigrahi \& Mishra (1984) indicated the latter when they investigated several problems concerning $M$. roxburghiana (a more elaborate account can be found under note 3 of the generic description)

The second generic synonym Saccopetalum was established in 1840 by Bennett with the species $S$. horsfieldii Benn. based on a collection by Horsfield from Java. Bennett recognised the similarity between Hyalostemma, Miliusa and Saccopetalum with the difference between the three genera being the number of ovules (Hyalostemma only one, Miliusa two, Saccopetalum more than two). A further difference between Sac- 
copetalum and Miliusa was that the first is deciduous and the latter not. Baillon (1868) considered these characters insufficient to keep the two genera separate and transferred Saccopetalum to Miliusa. Baillon did not make all needed new combinations, this was done later by Sinclair (1955).

Finet \& Gagnepain (1906) distinguished two sections within Miliusa based on the number of ovules. Section Saccopetalum (Benn.) Finet \& Gagnep. contains the species with at least four ovules and section Miliusa with never more than two. In their later publications they did not refer to these sections anymore. Only Fries (1959) and Huber (1985) still recognised the two sections. Both authors noted that all members of section Miliusa occur in the north-western (mainland Asia) part of the geographic distribution area, while the species in section Saccopetalum are found in the entire range of the genus. In the molecular study (Mols et al., in prep.), including only seven species of the genus, the representatives of section Miliusa are included in a strongly supported clade. Sampling of section Saccopetalum was insufficient to confirm its monophyly.

The genus consists, after the revision of the Austro-Malesian species, of c. 30 to 40 species. Although for the revision presented here the material outside the targeted area has also been studied, the problems on nomenclature and status of species occurring outside the Austro-Malesian area have not been sufficiently resolved and studied in detail. There are many species in India and China that are quite similar and/or only known from type material. Thailand may harbour several new species. As far as we know none of the remaining unrevised Miliusa species or unidentified material can be regarded as a synonym of the species dealt with here.

\section{Distribution}

The genus can be found from India and Bhutan to Australia and New Guinea. Most species occur in mainland Asia. The centre of distribution seems to be either Thailand or India, as both countries harbour a large number (10-15) of species, with some species shared by these countries.

The species currently revised are mainly confined to the Flora Malesiana area (Peninsular Malaysia to New Guinea including the Philippines) and Australia, here referred to as 'Austro-Malesian'. Several species of course extend outside this area and can also be found in mainland Asia.

\section{Ecological biogeography}

Some species exhibit a deciduous life cycle, which is correlated with their distribution. The young, new leaf flush is often accompanied by intensive flowering. The association of deciduousness with distribution, restricted to areas with seasonal climate, is best observed in Miliusa horsfieldii. This species has the widest distribution within the genus. It was known from Australia and Java only, but our present study reveals that it occurs in the seasonal areas from Hainan and mainland Asia to New Guinea and Australia (Map 1), showing some gaps, primarily in Sumatra, Borneo and most of New Guinea.

This distribution of $M$. horsfieldii can be explained by its adaptation to seasonal droughts, typical for the monsoon forest. When comparing the distribution of $M$. horsfieldii with the overall distribution of seasonal plants in general (Map 2 from Van Steenis, 1979) the localities of the specimens of the species coincide for c. $95 \%$ with the hatched (dry or seasonal) areas. Only in a few cases it seems that the localities of 


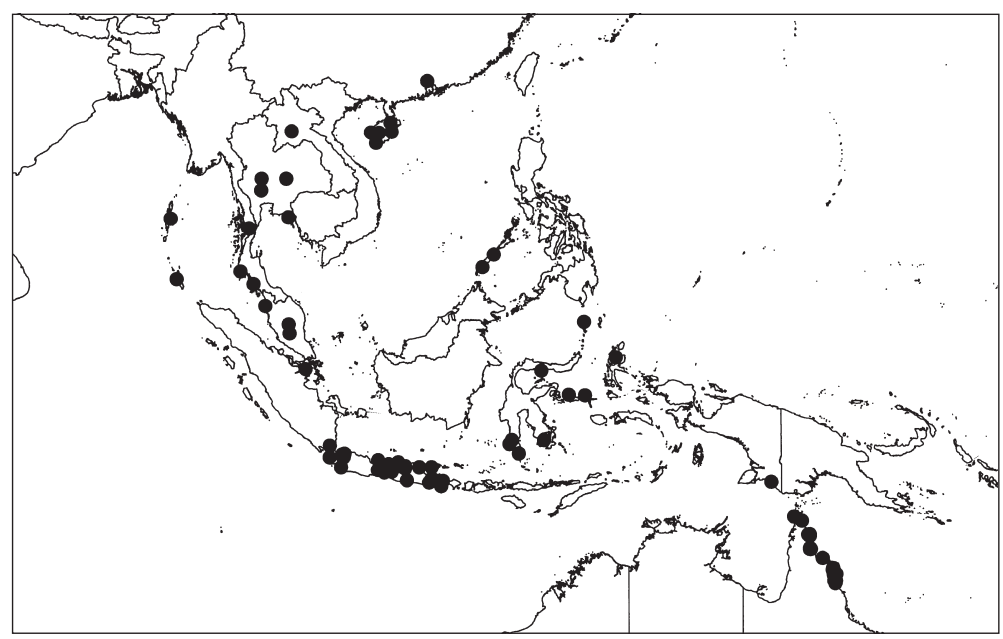

Map 1. Distribution of Miliusa horsfieldii (Benn.) Pierre.

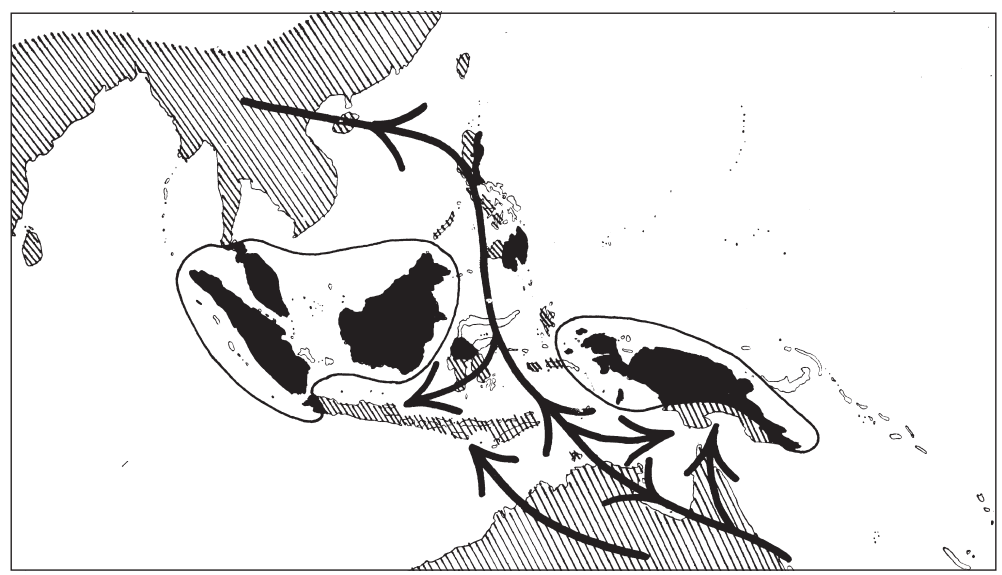

Map 2. Distribution of deciduous forests in Southeast Asia (hatched area), after Van Steenis (1979).

M. horsfieldii do not coincide with Van Steenis' general figure; in this case we may be dealing with dry enclaves within the rain forest belt. The latter is certainly the case for Miliusa koolsii (Kosterm.) J. Sinclair, which is endemic to New Guinea (Map 3). When comparing the localities in Papua with the annual rainfall in the area (Ridder, 1995 ) it becomes evident that these localities coincide with the places with the least annual rainfall.

In total six out of the ten species studied are deciduous and for all of these their localities coincide with the seasonal climate or with drier enclaves within their distribution area: Miliusa novoguineensis Mols \& Keßler, endemic to New Guinea occurs in some of the same localities as M. koolsii. Miliusa horsfieldii, M. brahei (F. Muell.) Jessup and 


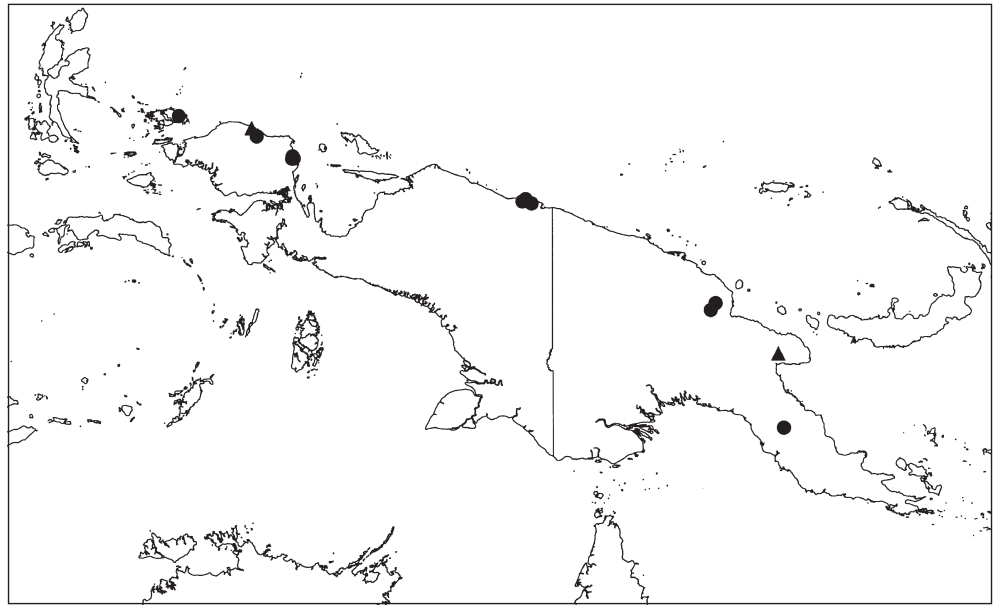

Map 3. Distribution of Miliusa koolsii (Kosterm.) J. Sinclair (•) and M. novoguineensis Mols \& $\operatorname{Keßler}(\boldsymbol{\Delta})$.

M. traceyi Jessup are restricted to the coastal areas of North Australia, which are seasonal and dominated by the monsoonal low-pressure systems, with summer rainfall and dry winters (mesophyl and notophyl forests, Beadle, 1981). Miliusa vidalii J. Sinclair is endemic to the Philippines, where it is restricted to seasonal and semi-seasonal areas (Wyatt-Smith, 1979).

Four species studied here are evergreen. The relatively widespread Miliusa longipes King can be found in Western Java, Sumatra, Peninsular Malaysia and mainland Asia. Most of these areas are covered with evergreen rain forest. Miliusa amplexicaulis Ridl. and $M$. parviflora Ridl. (the latter species is considered semi-deciduous) are respectively restricted to Peninsular Malaysia and Thailand, or Peninsular Malaysia alone. As mentioned before, these are areas with a typical rain forest climate. Miliusa macropoda Miq. is endemic to Borneo and although not deciduous does seem restricted to the drier north-eastern coastal parts of the island (MacKinnon et al., 1997). Based on this information together with label notes stating that the species grows close to rivers and is occasionally found in inundated areas it seems that the species is only tolerant to a more seasonal climate on Borneo, thanks to its mesic habitats.

Jovet-Ast (1942) observed the somewhat fragmented distribution of the genus and more importantly the very local occurrence of most species. For this reason she suggested that Miliusa represents an old genus with some members having disappeared in certain areas. The antiquity of the genus is difficult to assess, although diversification of Annonaceae took place in the Early Cretaceous (Le Thomas, 1981). At least it is shown here that the distribution of Miliusa and its species is very closely correlated with the climate, especially concerning the deciduous species. Furthermore, the deciduousness is not restricted to the Austro-Malesian area alone. It is also evident in mainland Asia where Miliusa tomentosa (Roxb.) Baill. ex Finet \& Gagnep. and M. velutina (Dunal) Hook.f. \& Thomson are also known to be deciduous (pers. obs.). 


\section{Vegetative morphology and anatomy}

The genus consists primarily of treelets to trees up to c. $40 \mathrm{~m}$ high; the largest trees are Miliusa koolsii (up to $55 \mathrm{~m}$ tall) from New Guinea. Within the family some of the largest individuals are Mezzettia leptopoda (Hook.f. \& Thomson) King and Polyalthia pachyphylla King both c. $40 \mathrm{~m}$ tall and primarily found in Peninsular Malaya (Keßler, 1993).

In general, the wood is yellow when fresh, but turns darker on exposure. It is hard, heavy, elastic, straight-grained with a fine texture and smooth touch. The structure is diffuse-porous with distinct to faint growth rings which are delimited by darker and denser fibrous tissue (M. velutina, Pearson \& Brown, 1932; M. globosa (sub $M$. roxburghiana), M. horsfieldii (sub M.tectona) and M. velutina, Chowdhury \& Gosh, 1958). The moderately few to numerous pores are medium sized to large (50-200 $\mu \mathrm{m}$; M. horsfieldii (sub Saccopetalum horsfieldii, Moll \& Janssonius, 1906; M. koolsii, M. horsfieldii (sub M. unguiculatum), and M.velutina, Sidiyasa, 1998). The parenchyma is in fine tangential lines, forming a network with the narrow to moderately broad to broad rays, which is typical for Annonaceae (Pearson \& Brown, 1932; Chowdhury \& Gosh, 1958; Keßler, 1998; Sidiyasa, 1998). The wood is reportedly easy to work, but is not very durable, and is therefore not dealt with on a large scale. The wood is primarily used for tool handles or in cheap constructions, furniture and packing cases (M. velutina, Foxworthy, 1909; Pearson \& Brown, 1932; Chowdhury \& Gosh, 1958; Keßler, 1998). The wood of the Australian species M. brahei is used by the aboriginals in light building and crafting and the boiled inner bark is used to dye fibrecrafts yellow to orange (Lindsay et al., 2001). Moll \& Janssonius (1906) mentioned that the wood resembles that of Mitrephora, Orophea, Platymitra, Trivalvaria Miq. and Popowia Endl.

Hallé \& Oldeman (1970) classified most Annonaceae in two different architectural models, either Roux' model or Troll's model. Johnson (in prep.) noted that the species with Roux's model have the branches spirally arranged on the trunk, while the species with Troll's model have the branches distichously arranged. Like most Asian members of Annonaceae Miliusa has a spiral pattern on the primary axis. The arrangement of the entire leaves on the branches is distichous, as in almost all Annonaceae. The shape of the leaves varies to some extent between species, but more importantly also within species and even individual trees. Therefore it is difficult to use leaf characters for taxonomic delimitation. The shape of the leaves often varies depending on age, especially in the deciduous species. The mature leaves in M. horsfieldii, for instance, are elliptic to ovate, but the young ones are often obovate. Also the shape of the base can differ within a species, even within the leaves of one specimen. In M. horsfieldii the base is always unequal, with the young leaves having a more acute to rounded base, while in the older leaves the bases often are emarginate. The unequal base is somewhat characteristic for some species, as the base is almost always unequal in M. amplexicaulis, M. horsfieldii, $M$. macropoda and M. vidalii, while only rarely so in $M$. koolsii, M. novoguineensis and $M$.traceyi. In M. amplexicaulis the unequal half of the leaf base is clasping the petiole and/or branch, hence the name. Generally the apex of the leaves is acute to cuspidate, but the length of the elongated apex may be less prominent in younger leaves. Patel (1971) studied the epidermal structure and stomata of $M$. tomentosa. The epidermal cells contain crystals of calcium oxalate of various shapes. The stomata are paracytic and randomly distributed between the veins. 
The venation is quite similar in all species in having approximately 7-12 straight secondary vein pairs which anastomose reasonably far from the margin $(4-10 \mathrm{~mm})$, the midrib above is flat or slightly sunken but prominent below. Almost all species have intersecondary veins, which are more obvious in some species. Klucking (1986) classified the main venation type within Miliusa as 'middle phase venation' being dominant with some amounts of 'early' and 'late phase' present in the lower and upper parts of the leaves, respectively. The latter indicates that the angle between midrib and secondary veins differs at the base and apex of the leaves. This difference in angle between midrib and secondary veins at the base of the blade was also used by Chen \& $\mathrm{Li}$ (1993) to indicate the difference between Miliusa (angle at the base 30-45 ) and Saccopetalum $\left(75-85^{\circ}\right)$ and maintained them as separate genera. Although a general trend within a species is seen, in most cases the angles at the base are larger, but in three species they are smaller at the base (M. amplexicaulis, M. koolsii and M. longipes), and it is not uniform within a species or even one specimen. These features are also not useful in section or genera delimitation.

The indument consists only of simple hairs, either mostly appressed (strigose), short semi-erect (tomentose) or more dense and composed of soft hairs (pilose). For the dense cover of short, soft hairs on the inside of the inner petals the term 'pubescent' is used. The hairs on stigmas, when present, are very thin and long (in comparison with the stigmas) for this the term 'cobwebbed' is used, after Hewson (1988). In the descriptions the indument density has been subdivided in three types: dense (hardly any epidermal surface visible), normal (surface visible) or sparse (just a few hairs). The hairs of the Indian species Miliusa tomentosa have been studied in more detail by Aleykutty \& Inamdar (1980). They described the hairs as eglandular, multicellular (3 or 4), uniseriate simple filiform hairs (also described as such by Patel, 1971), which consist of a simple foot and uniseriate body with narrow tip. This type of hair is common among Annonaceae.

\section{Inflorescence and flowers}

The general inflorescence structure within Miliusa is a rhipidium, or a reduced cyme (Weberling, 1981). This means that within the inflorescence the basal flower is the oldest. When there are more flowers in an inflorescence each flower is in a different stage of maturity. In $M$. traceyi the younger flowers never fully mature as the additional buds fall off when the basal flower reaches full maturity. In two species, M. brahei and $M$. horsfieldii, no bracts were found, only 2 bracteoles. In all other species a bract and one bracteole can be recognised. The bracteoles and some bracts are caducous and are very tender and easily damaged: in many dried flowers the bracteole was absent and only a tuft of hairs indicated the former locality of this bracteole.

The bisexual flowers (Fig. 4c, d) show one whorl of three sepals and two whorls of three petals each. The outer petals and the sepals are alike in shape and size, although not identical as in Phaeanthus Hook.f. \& Thomson. The sepals are often triangular or tongue-shaped, while the outer petals are either tongue-shaped, triangular or boatshaped (Fig. 1), when they do look alike the sepals are smaller than the outer petals. When the outer petals are boat-shaped they enclose the margins of two adjoining inner petals. At anthesis when the inner petals separate, the outer petals often fall off (although they often remain enclosed between the inner ones). In M. amplexicaulis 


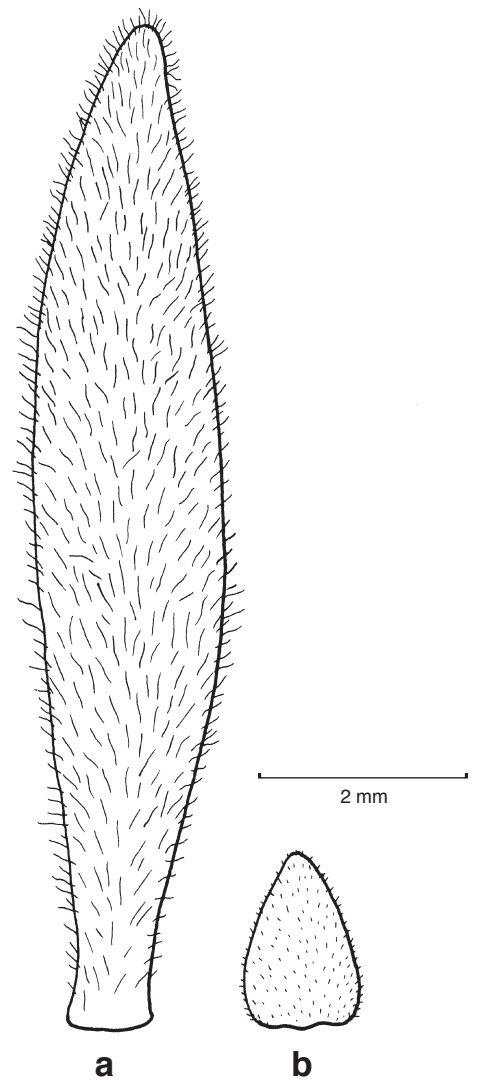

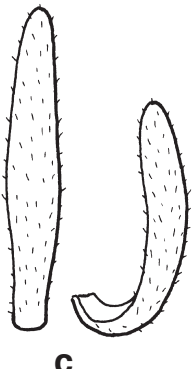

C
Fig. 1. Outer petals. a. Tongue-shaped (M. horsfieldii (Benn.) Pierre); b. triangular (M.macropoda Miq.); c. boatshaped (M. koolsii (Kosterm.) J. Sinclair) (a: Jessup 644; b: Sidiyasa et al. B 1244; c: Carr 16518).

the sepals are connate at the base. The inner petals are broadly triangular or narrowly ovate (M.novoguineensis and $M$. traceyi) and traditionally characterised by a saccate base, unique for this genus. The size of the sac can differ between species. The sac often seems to consist of glandular tissue which runs along the midrib to the apex. This tissue is visible in dried material because of a difference in colour. This is also seen in living material as the midrib and the base are often red in comparison with the creamy to greenish yellow colour of the remainder of the inner petals. But Sinclair (1955) indicated that not all Miliusa species had inner petals with a saccate base: $M$. amplexicaulis, $M$. andamica, $M$. parviflora and $M$. velutina were considered to be non-saccate. Additionally, M. amplexicaulis differs from the other Miliusa species in having a thick arc of glandular tissue at the base instead of running along the midrib. The fact that these species had no sac and in the case of $M$. amplexicaulis that the species had this glandular ring at the base (together with some other characters; e.g. the connate sepals which is shared by a number of mainland species such as $M$. fusca Pierre, M.glandulifera C.E.C. Fisch., M. glochidioides Hand.-Mazz., M. mollis Pierre var. mollis, M. mollis Pierre var. sparsior Craib) seemed to warrant the exclusion of these species from Miliusa. But the molecular analyses (Mols et al., in prep.) have shown that Miliusa can only be considered monophyletic when all these non-saccate 
species are included. In the same molecular study M. amplexicaulis and allies were represented by two accessions of $M$. mollis var. mollis and the non-saccate species by M. velutina.

The torus of Miliusa is characterised by long pilose hairs surrounding the stamens and these hairs often persist in fruit. Very few other genera show this uncommon character. The torus bears in the middle 3 to 80 carpels surrounded by 3 to 232 stamens. The stamens primarily consist of a connective with two extrorse anthers on a short filament. They are called miliusoid, which means that the connective prolongation does not extend over the anthers and ends into a short and obtuse apex. This in comparison with the other stamen types of Annonaceae in which the connective prolongation extends over the anthers and forms a shield-like structure. The carpels are flask-shaped and the stigmas are sessile. At anthesis the stigmas are covered with an exudate. The number of ovules varies from 1 to 12 , with a few in M.longipes, $M$. novoguineensis and $M$. traceyi, while in the other species more ovules are found. The placentation of the ovules is correlated with the number of ovules. Species with one or two ovules have a (basi) lateral uniseriate placentation, while the species with more ovules have a lateral biseriate placentation. Miliusa macropoda, however, has 5 to 10 ovules which are uniseriate. Sastri (1957) found that the ovules in M.tomentosa (sub Saccopetalum tomentosum) arise from the ventral side which makes the placentation laminar. The margins of the carpels are very close but never fuse. The wall contains three veins, of which only the one dorsal vein supplies the ovules.

\section{Pollen}

Walker (1971) studied the pollen of most annonaceous genera and classified the genera into three subfamilies and eight tribes. Miliusa was placed in the Malmea subfamily in the Uvaria tribe, which is the largest recognised tribe with 47 genera. Walker described the pollen of Miliusa as solitary, apolar, radiosymmetric, globose and inaperturate. They are medium-sized to large and tectate with well-developed columellae. When comparing the pollen of Miliusa with that of the other genera in the tribe using Walker's data, it is very difficult to distinguish between the genera. In recent years the pollen of some genera in Annonaceae has been re-studied with the emphasis on the inaperturate pollen. Doyle \& Le Thomas $(1994,1996,1997)$ and Doyle et al. (2000) stated in their cladistic analysis of Annonaceae based on, among others, morphological characters that the pollen type in Miliusa should not be interpreted as being inaperturate but as disulculate. Based on preliminary observations it had already been suggested by Waha \& Morawetz (1988) that in Miliusa disulcate pollen could be found, but Doyle \& Le Thomas (1994) stated that the sulci are not polar and the pollen should therefore be described as disulculate (Waha \& Hesse, 1988: f. 4a). According to Le Thomas (1980) and Le Thomas et al. (1986) the exine consists of a very thin discontinuous strongly aerolate-verrucate tectum with a weakly developed granular infratectal layer with a foliated basal layer, while the intine is fibrillar, lacunar and thick.

Leopold (1969) mentioned Miliusa type pollen for the Miocene of Viti Levu, Fiji. Unfortunately, he neither gave a description of the pollen, nor the reasons why it should belong to Miliusa. Leopold erroneously stated that no Annonaceae are known from Fiji: six genera occur (Smith, 1981) on this island group, though no Miliusa. This means that either Miliusa used to be present in this area and is extinct now, or it concerned 
the pollen of a different Annonaceae genus. The latter appears to be the most plausible explanation. Most likely we are dealing with pollen of Polyalthia, which is also placed in the Uvaria tribe sensu Walker (1971) as it has quite similar pollen to that of Miliusa (Doyle \& Le Thomas, 1994). Nine Polyalthia species occur on Fiji, all endemic.

Periasamy \& Swamy (1959) studied the microsporogenesis in Miliusa wightiana Hook.f.\& Thomson. They concluded that Miliusa differs from Cananga odorata (Lam.) Hook.f. \& Thomson, in having microsporangia containing massive sporogenous tissue instead of a single strand. Additionally the division of the microspore mother cell is said to be of the simultaneous type. This is not necessarily the general condition in the genus, however. Sastri (1969) indicated that in M. tomentosa (sub Saccopetalum tomentosum) the microspore mother cell division is not simultaneous, but should be described as modified simultaneous, as the furrowing starts at the first meiotic stage and is completed only at the end of the second division.

\section{Carpidia}

The monocarps are (sub)globular to elliptic to irregular-shaped, up to $4 \mathrm{~cm}$ long and $3 \mathrm{~cm}$ wide. The shape differs with the number of seeds. The monocarps are always glabrous and stipitate. The fruitlets are not positioned in a straight line with the stipe, but obliquely inserted giving it the appearance of a hockey stick or golf club. The pericarp differs greatly within the genus. It can be either thin and paperlike (M. longipes) or very thick, hard and leathery (M. horsfieldii) when dry. In the first case in dried specimens the raphe is often visible through the pericarp. The unripe fruits are yellow green to green ripening red to dark purple. The number of monocarps can range from 2 to 40, with large differences even within one specimen. Each monocarp can contain up to 10 seeds. The seeds are generally elliptic but when more seeds are present the sides flanking other seeds are often flattened, which alters their shape. The raphe consists of a shallow straight groove and the hilum is transversely elliptic or circular and only a few mm wide. The seed wall is rather thin (papyraceous). Ruminations are lamellate, dividing the seed in four parts.

Corner $(1949,1976)$ suggested that the seeds of $M$. wightiana resemble those of Polyalthia sclerophylla Hook.f. \& Thomson (sub P. purpurea) in having a testa that is little differentiated because having no longitudinal fibres, a small hilum, an inner integument which is only a single layer of cells, endosperm which is white, starchy and hard, and having ruminations which are formed by the inner integument. Miliusa differs from Polyalthia species in lacking oil cells in the ruminations. Periasamy \& Swamy (1961) studied the ovule and seed development in M. wightiana Hook.f. \& Thomson and found that the ovules are bitegmic throughout with no middle integument. Furthermore, the plate-like rumination ingrowths in Miliusa consist of both the inner and outer integument. These ingrowths are broken along median and transmedian longitudinal planes, which confines the growth to four sectors of the seed (lamellate in four parts sensu Van Setten \& Koek-Noorman, 1992).

The fruits of some species are sold on the local market because of their fleshy coat (e.g. M. brahei, Yunupinu et al., 1995).

\section{Karyology}

Chromosome numbers of several Miliusa species are recorded as $2 \mathrm{n}=18$. The species studied are: M. globosa (Okada \& Ueda, 1984, sub M. roxburghiana), M. longiflora 
(Hook.f. \& Thomson) Baill. ex Finet \& Gagnep. (Löve, 1982), M. tomentosa (Adatia \& Chokshi, 1951, sub Saccopetalum tomentosum), M. velutina (Löve, 1979), and M. brahei (Morawetz, 1988). Miliusa eriocarpa Dunn is said to have $\mathrm{n}=14$ (Löve, 1980); this number is not common in Annonaceae, only having been reported in Annona L., Unonopsis R.E. Fr., Guatteria Ruiz \& Pav. and Anaxagorea A.St.-Hil. (Walker, 1972; Morawetz, 1986), of which only Anaxagorea is found in Asia. Possibly the specimen used by Löve was wrongly identified, although this could not be verified.

\section{Reproductive biology}

Few Aut-ecological studies on Asian Annonaceae have been carried out and little is known concerning Miliusa. Okada (1990) studied the flower phenology of several Annonaceae in the Bogor Botanical Garden in 1980 and 1981. He found that Miliusa globosa (sub Miliusa roxburghiana) flowers the whole year round, while the different Miliusa horsfieldii trees synchronously flowered only twice in the 18 months of study, simultaneously with flushing of the leaves. Each flowering period of $M$. horsfieldii lasted circa two months.

The plants are supposed to be pollinated by beetles, as on several occasions allegedly beetle dung has been found in herbarium specimens. Personal observations of Miliusa horsfieldii during a short visit at the Botanical Garden Bogor did not confirm this. The only insects observed surrounding and visiting the flowers during a short series of observations were fruit flies. In a few cases flies are proven or suspected pollinators of Annonaceae (Morawetz, 1988; Norman et al., 1992; Gottsberger, 1999). The fly pollinated flowers are said to remain open at anthesis and the petals do not fold over the reproductive organs and the floral odours are either imperceptible or unpleasant, yeasty. The flowers of $M$. horsfieldii remain wide open after anthesis and the smell is, although not very strong, not unpleasant, although for M. macropoda it has been stated that the smell is like fermented rice. Further studies are needed to reveal the actual pollinator(s).

\section{Medicinal uses and phytochemistry}

Greshoff mentioned in 1898 that the bark of M. longiflora and M. horsfieldii (sub Saccopetalum longiflorum and $S$. horsfieldii respectively) contained alkaloids, although in very low amounts. In more recent studies the bark extracts of M. velutina are said to be purgative (Yoganarasimhan et al., 1982) and Shah \& Gopal (1982) specified that the bark decoction of $M$. tomentosa is used in the treatment of rheumatism and that the fruits were anti-diuretic. Bhargava \& Chauhan (1968) and Kar \& Jain (1971) investigated the essential oil of this species (sub Saccopetalum tomentosum) for antibacterial activity and the oil was found to be somewhat active against both Gram-positive and Gram-negative bacteria. The essential oils were tested on mammals (Menon \& Kar, 1970) where the oils caused a reduction in the motor activity, blocked responses, exerted a central depressed action and analgesic effect in rats and a pentobarbitione hypnoses in mice. From the roots of M. balansae Finet \& Gagnep. (sub M. banacea) two oxoapophine alkaloids, one new to science, were isolated and together with a total extract from the roots tested for bioactivity. The extracts showed selective toxicity against DNA repair and recombination deficient mutants of the yeast Saccharomyces cerevisiae (Harrigan et al., 1994). Four alkaloids have been extracted from the bark of $M$. velutina. The benzylisoquinoline and aporphine alkaloids found are typical for 
all Annonaceae. Oxoapophine alkaloids were also found, which are not typical for the family, and the authors therefore suggest a close relationship between $M$. velutina and M. balansae (Jumana et al., 2000).

\section{KEYS AND DESCRIPTIONS}

\section{MILIUSA - Map 4}

Miliusa Lesch. ex A.DC. (1832) 37. - Type: Miliusa leschenaultii A.DC.

Hyalostemma Wall. (1836) No. 6434. - Type: Hyalostemma roxburghiana Wall. nom. illeg. pro Hyalostemma dioica (Roxb.) Wall.

Saccopetalum Benn. (1840) 165, t. 35. - Type: Saccopetalum horsfieldii Benn.

Shrubs or trees up to $40(-55) \mathrm{m}$ tall. Old branches terete, fissured, lenticelled, when older flaky; lenticels elliptic. Young branches terete, sometimes square or flattened in transverse section. Petioles above (slightly) grooved or flat, below wrinkled, sometimes base thickened. Leaves obovate, elliptic or ovate, papyraceous to pergamentaceous (M. koolsii), above glossy; base often unequal, rounded to cuneate, sometimes emarginate; apex acute to slightly cuspidate; midrib above flat or slightly sunken, seldom raised ( $M$. traceyi and $M$. brahei), below prominently raised; secondary veins straight with sometimes intersecondary veins, anastomosing, reticulation often not visible. Inflorescences reduced cymes, axillary, extra-axillary or seldom terminal, 1-3(-5)flowered; pedicels with an articulation at the base; peduncles and pedicels often enlarged and thickened when fruiting; bud scales 2 , transversely ovate, apex rounded to acute, somewhat clasping the branch; bract(s) $0-4$; bracteole(s) 1 or 2 (M. brahei and $M$. horsfieldii), often caducous and only tuft of hairs still present. Flowers bisexual. Sepals 3, valvate, tongue-shaped to triangular, not persisting in fruit. Outer petals 3, valvate, tongue- or boat-shaped, not persisting in fruit. Inner petals 3, valvate, (narrowly) ovate to triangular, base saccate (except $M$. parviflora and $M$. amplexicaulis), tissue of midrib and sac often deviating (glandular?), visible as a colour difference in dried material, in M. amplexicaulis seen as a thickened arc at the base of the inner petal. Torus (elongated) hemispherical to subglobular, densely pilose when flowering, flattened globose, glabrescent when fruiting. Stamens 3-232, miliusoid, connective prolongation short and obtuse or acute (M. amplexicaulis); anthers 2 per stamen, extrorse with visible connective; staminodes $0-6$, resembling shape of connective with or without underdeveloped anthers, placed in the lowest whorl of stamens. Carpels 3-80, (round) flask-shaped, peripheral ones more bend, glabrous or strigose; style absent; stigma capitate to club-shaped, glabrous or cobwebbed, covered with exudate; ovules 1-12, (basi) lateral, uni- or biseriate. Monocarps 2-43, (sub)globular to elliptic to irregular shaped, obliquely placed on stipe; stipe terete, sometimes grooved, articulated at the base, when dried brown to black, glabrous. Seed(s) 1-9, elliptical, sometimes flattened on one or two sides, ruminations lamellate in 4 parts.

Distribution - India, Sri Lanka, China, Myanmar, Thailand, Laos, Vietnam, Cambodia, Nicobar and Andaman Islands, Malaysia, Singapore, Indonesia, Philippines, New Guinea, Australia.

Notes - 1. Drummond (1920) was the first to notice that De Candolle used two names for the type species, in the text $M$. indica (the name given by Leschenault de la 


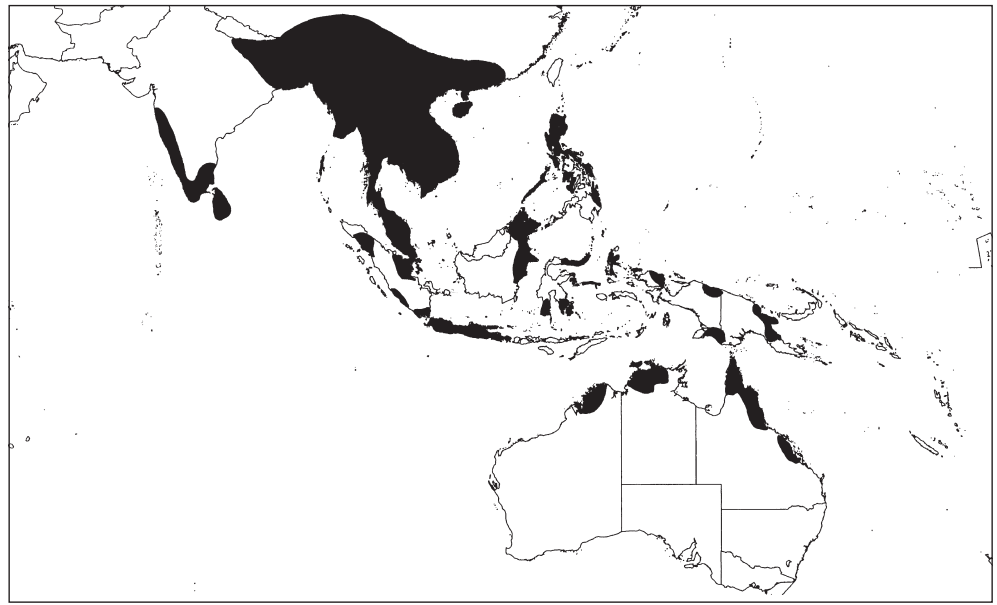

Map 4. Distribution of Miliusa A.DC.

Tour) and on the accompanying plate $M$. leschenaultii. As both names were published at the same time a choice needed to be made. Drummond seems to have made the choice when he stated, to conclude the part of his article concerning the taxonomic problems of this species, “... local botanists will presumably keep up Miliusa leschenaultii (type of the genus), M.affinis, M. montana, and M. nilagirica as distinct ...", indicating that $M$. leschenaultii should be used. In contrast, however, $M$. indica has been used till the present time (actually so far M. leschenaultii has never been found in literature except in De Candolle and Drummond). Nevertheless following Drummond we propose that $M$. leschenaultii should be used as the correct name for the type species.

2. De Candolle described the new genus on a specimen that only had three petals united at the base, and their bases being saccate. The first two characters and some additional ones mentioned in the protologue do not fit the general perception of Miliusa leschenaultii or the genus as a whole based on all material available. The inner petals within Miliusa are not connate at all. However, of the first flower of the type material (Leschenault de la Tour s.n., Mt De Cottalam, 1823; G-De Candolle holotype, A, P, isotypes) we checked the inner petals and these were indeed connate, or at least not easily separable without damaging the laminas. This was not the case in another flower of the material and any other flower of this species. In many species of Miliusa the inner petals only separate just before anthesis. De Candolle also stated in his description that the flower consists of only one whorl of three sepals and one whorl of three petals, which is in contrast to the overall pattern in the family and also in Miliusa. In Miliusa, like most Annonaceae, the flowers consist of one whorl of three sepals and two whorls of three petals with the outer whorl being smaller and resembling the sepals. The shape and size of the described 'sepals' is like the outer petals in the other material of the species, so it seems that De Candolle missed the sepals. When checking the original material no additional sepals/petals could be found, not even scars of a possible sepal whorl. Drummond (1920) suggested that the sepals might have been caducous, but this has not been seen in any of the specimens studied in detail for the Austro-Malesian region. It must be concluded that the type material is aberrant. 
3. Wallich transferred in his Numerical List (1832) under 6434 a species by Roxburgh, Uvaria dioica ('dioeca') Roxb. to the new genus Hyalostemma, but named the type species Hyalostemma roxburghiana instead of $H$.dioica. Lindley (1836) later described the genus in more detail by adding more of Roxburgh's original description. Meisner $(1837,1839)$ also gave a description of the genus but quoted Wallich in mentioning the only species as Hyalostemma roxburghiana. When Hooker \& Thomson (1855) transferred Hyalostemma to Miliusa they used Wallich's name and named the species $M$. roxburghiana, which now must be considered a superfluous name. Kurz (1870) transferred Miliusa roxburghiana to the genus Phaeanthus and stated that Uvaria dioeca was the oldest name for this species. This meant the new species would be called Phaeanthus dioica (Roxb.) Kurz. Later he transferred the species back to Miliusa, but unfortunately again under the name M.roxburghiana with Uvaria dioica as a synonym (Kurz, 1874). Panigrahi \& Mishra investigated the problems concerning the species $M$. roxburghiana and indicated that $H$. roxburghiana was a superfluous name. The combination Hyalostemma dioica has never been made (Panigrahi \& Mishra, 1984).

\section{KEY TO THE SPECIES}

1a. Leaf base equal or unequal, not clasping petiole and/or branch. Sepals free. Inner petals with or without a sac, without thickened arc of glandular tissue. . . . . . 2

b. Leaf base unequal, clasping petiole and/or branch. Sepals connate at the base. Inner petals without a sac at base, with thickened arc of glandular tissue. - Thailand, Peninsular Malaysia . . . . . . . . . amplexicaulis

2a. Inner petals $>5 \mathrm{~mm}$, with a sac, with or without distinct glandular tissue on midrib or base. Stamen connective prolongation obtuse $\ldots \ldots \ldots \ldots \ldots \ldots \ldots$

b. Inner petals $\leq 5 \mathrm{~mm}$, without a sac and distinct glandular tissue on midrib or base. Stamen connective prolongation acute. - Thailand, Peninsular Malaysia . . . . .

8. M. parviflora

3a. Inner petals narrowly oblong ovate without distinct glandular tissue. Stamens $<10$

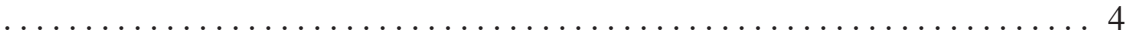

b. Inner petals ovate or triangular with distinct glandular tissue. Stamens $\geq 15 \ldots 5$

4a. Leaves (broadly) elliptic, ratio 2.4-3.6. Sepals and outer petals $\leq 1.5 \mathrm{~mm}$. Staminodes 1-3. Carpels < 12. - New Guinea ......... 7. M. novoguineensis

b. Leaves elliptic to ovate, ratio 1.7-2.4. Sepals and outer petals $>1.5 \mathrm{~mm}$ long. Stami-

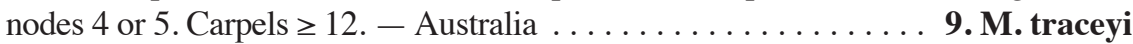

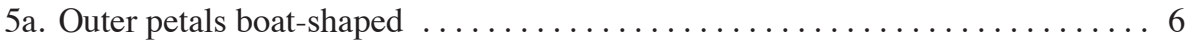

b. Outer petals triangular or tongue-shaped $\ldots \ldots \ldots \ldots \ldots \ldots \ldots \ldots$

6a. Bracts 1-4. Bracteole 1. Carpels $\leq 18$. Ovules $\geq 8 \ldots \ldots \ldots \ldots \ldots \ldots \ldots$

b. Bracts absent. Bracteoles 2. Carpels $>20$. Ovules $<8$. - Australia . . 2. M. brahei

7a. Leaf base equal, acute to slightly cuneate or rounded. Indument strigose. Pedicels $9-25(-45) \mathrm{mm}$ long. Sepals $<1.5 \mathrm{~mm}$ long. Monocarp stipe $\geq 16 \mathrm{~mm}$. - New

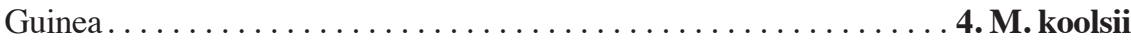

b. Leaf base unequal, slightly emarginate. Indument pilose. Pedicels 29-145(-215) mm long. Sepals $\geq 1.5 \mathrm{~mm}$ long. Monocarp stipe $<16 \mathrm{~mm}$. - Philippines . . . . . 
8a. Sepals and outer petals triangular. Sepals $\leq 2 \mathrm{~mm}$ long. Outer petals $\leq 2.5 \mathrm{~mm}$ long. Inner petals ovate. Monocarp pericarp papery (up to $1.5 \mathrm{~mm}$ ) . . . . . . . . . 9

b. Sepals and outer petals tongue-shaped. Sepals $>2.5 \mathrm{~mm}$ long. Outer petals $\geq 3.5$ $\mathrm{mm}$ long. Inner petals triangular. Monocarp pericarp leathery $(1-4 \mathrm{~mm}) \ldots \ldots$ 3. M. horsfieldii

9a. Inner petal sac $\leq 2.5 \mathrm{~mm}$ high. Stamens $<30$. Carpels $<50$. Ovules 2 . Seed(s) 1 or

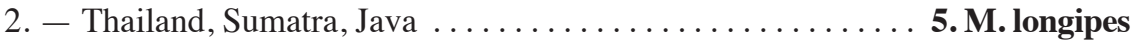

b. Inner petal sac $>2.5 \mathrm{~mm}$ long. Stamens $>100$. Carpels $\geq 50$. Ovules $5-10$. Seeds 3-6. - Borneo.

6. M. macropoda

\section{SYNOPTICAL KEY TO THE SPECIES}

The numbers refer to the species descriptions: $1=M$. amplexicaulis; $2=M$. brahei; $3=M$. horsfieldii $; 4=M$. koolsii $; 5=M$. longipes $; 6=M$. macropoda $; 7=M$. novoguineensis; $8=M$. parviflora $; 9=M$. traceyi; $10=M$. vidalii (numbers cited under only one lead of a couplet are indicated in bold). When a given character is unknown for a species the species is not listed.

Deciduousness

a) deciduous

$2,3,4,7,8,9,10$

b) not deciduous

$\mathbf{1}, \mathbf{5}, \mathbf{6}, 8$

Leaf base

a) unequal, clasping petiole and/or branch 1

b) unequal, not clasping petiole and/or branch

$\mathbf{3}, 4, \mathbf{6}, 7,9,10$

c) equal

$\mathbf{2}, 4, \mathbf{5}, 7, \mathbf{8}, 9$

Leaf base

a) emarginate

$3,6,9,10$

b) never emarginate

$1,2,4,5,6,7,8,9,10$

Pedicel length (mm)

a) $\leq 26$

$\mathbf{1}, \mathbf{3}, 4,5,7, \mathbf{8}, 9$

b) $>26$

$2,4,5,6,10$

Sepal length $(\mathrm{mm})$

a) $\leq 2.5$

$1,2,3,4,5,6,7,8,9,10$

b) $>2.5$

3,9

Outer petal shape

a) boat-shaped

$2,4,7,9,10$ b) (broadly) triangular to tongue-shaped $1,3,5,6,8$

Outer petal length $(\mathrm{mm})$

a) $\leq 1.4$

7,8

b) $>1.4$

$1,2,3,4,5,6,9,10$

Inner petal shape

a) ovate

$1,2,4,5,6,8,10$

b) narrowly ovate

7,9

c) triangular

3

Inner petal length $(\mathrm{cm})$

a) $\leq 0.5$

1,8

b) $0.5-1.5$

$1,2,4,5,6,7,9,10$

c) $>1.5$

3,5

Sac of inner petals

a) absent

1,8

b) $\leq 3 \mathrm{~mm}$ high

$\mathbf{2}, 3,4, \mathbf{5}, 6, \mathbf{7}, 9$

c) $>3 \mathrm{~mm}$ high

$3,4,6,10$

Inner petal

a) with thickened glandular arc at the base 1 
b) with distinct glandular tissue on the midrib and base

$$
2,3,4,5,6,10
$$

c) without distinct glandular tissue on the midrib and base $5,7,8,9$

Stamen number

a) $\leq 34$

$$
\mathbf{1}, 2,4, \mathbf{5}, 7,8,9
$$

b) $>34$

$$
2,3,4,6,8,10
$$

Carpel number

$$
\text { a) } \leq 20
$$

$$
1,3,4,5,7,8,9,10
$$

b) $21-49$

$$
1,2,3,5
$$

c) $\geq 50$

$$
6
$$

Ovule number

a) 1 or 2

$$
1,5,7,9
$$

b) 3 or more $2,3,4,6,8,10$
Monocarp number

a) $\leq 20$

$$
1,2,3,4,5,6,8,9,10
$$

b) $21-43$

5,6

Monocarp length $(\mathrm{cm})$

a) $\leq 2$

$\mathbf{1}, \mathbf{2}, 3,4, \mathbf{5}, 6, \mathbf{8}, \mathbf{9}, 10$

b) $>2$

$$
3,4,6,10
$$

Distribution

a) Peninsular Malaysia and mainland Asia $1,3,5,8$

b) Sumatra and Java 3,5

c) Borneo 6

d) Philippines 3,10

e) Moluccas and New Guinea $3,4,7$

f) Australia $2,3,9$

\section{Miliusa amplexicaulis Ridl. - Fig. 2; Map 5}

Miliusa amplexicaulis Ridl. (1910) 13. - Type: Curtis 3205 (holo K; iso UC), Malaysia, Peninsular Malaysia, Lankawi, Kwah, April 1896, fl.

Evergreen shrubs or treelets, 2.5-6 m tall, dbh $2 \mathrm{~cm}$. Twigs (sparsely) strigose or tomentose, glabrescent. Petioles $2-7$ by $1.5-4 \mathrm{~mm}$. Leaves obovate to elliptic, $9.3-26$ by $4-11 \mathrm{~cm}, 1 / \mathrm{w}$ ratio $2-2.5$, base unequal, broadly oblique with lamina clasping the petiole and/or branch, apex cuspidate $(-3.5 \mathrm{~cm})$, lamina above glabrous, below (sparsely) strigose to tomentose, glabrescent, midrib above flat or slightly sunken, secondary veins $12-18$ pairs with no obvious intersecondary veins, angle with midrib $45-60^{\circ}$, angles generally smaller at the base. Cymes axillary, 1 or 2 (or 3)-flowered; peduncles $2-4$ by $0.5 \mathrm{~mm}$; pedicels $7-25$ by $0.5 \mathrm{~mm}$; bud scales absent; bracts 2 , ovate, clasping the peduncle, $1-2.5$ by $0.7-1 \mathrm{~mm}$, apex not recurved; bracteole 1 , triangular, $1-1.5$ by $0.7-1 \mathrm{~mm}$, apex recurved, placed at c. $1 / 3$ to $1 / 2$ from base of pedicel, sometimes persisting when fruiting. Sepals triangular, connate at the base, $1.5-2$ by $1.5-2 \mathrm{~mm}$, midvein sometimes visible, not persisting when fruiting. Outer petals triangular, 2-3 by $1.5-2.5 \mathrm{~mm}$, apex not curved, veins 6 . Inner petals broadly ovate to triangular, $0.4-0.7$ by $0.4-0.7 \mathrm{~cm}, 0.5 \mathrm{~mm}$ thick, sac not present, base with thickened glandular tissue, arced, upper part warty, lower part smooth, apex acute, margins recurved, outside glabrous, inside glabrous except margins pubescent, veins not visible. Torus hemispherical, $1-2$ by $1-2 \mathrm{~mm}$ wide. Stamens $11-31,0.5-1$ by $0.5-1 \mathrm{~mm}$, connective prolongation obtuse; staminode(s) $1-6,0.5-0.8$ by $0.3-0.5 \mathrm{~mm}$ wide. Carpels 4-36, flask-shaped, $0.5-1$ by $0.4-0.7 \mathrm{~mm}$, glabrous; stigma capitate to club-shaped, 


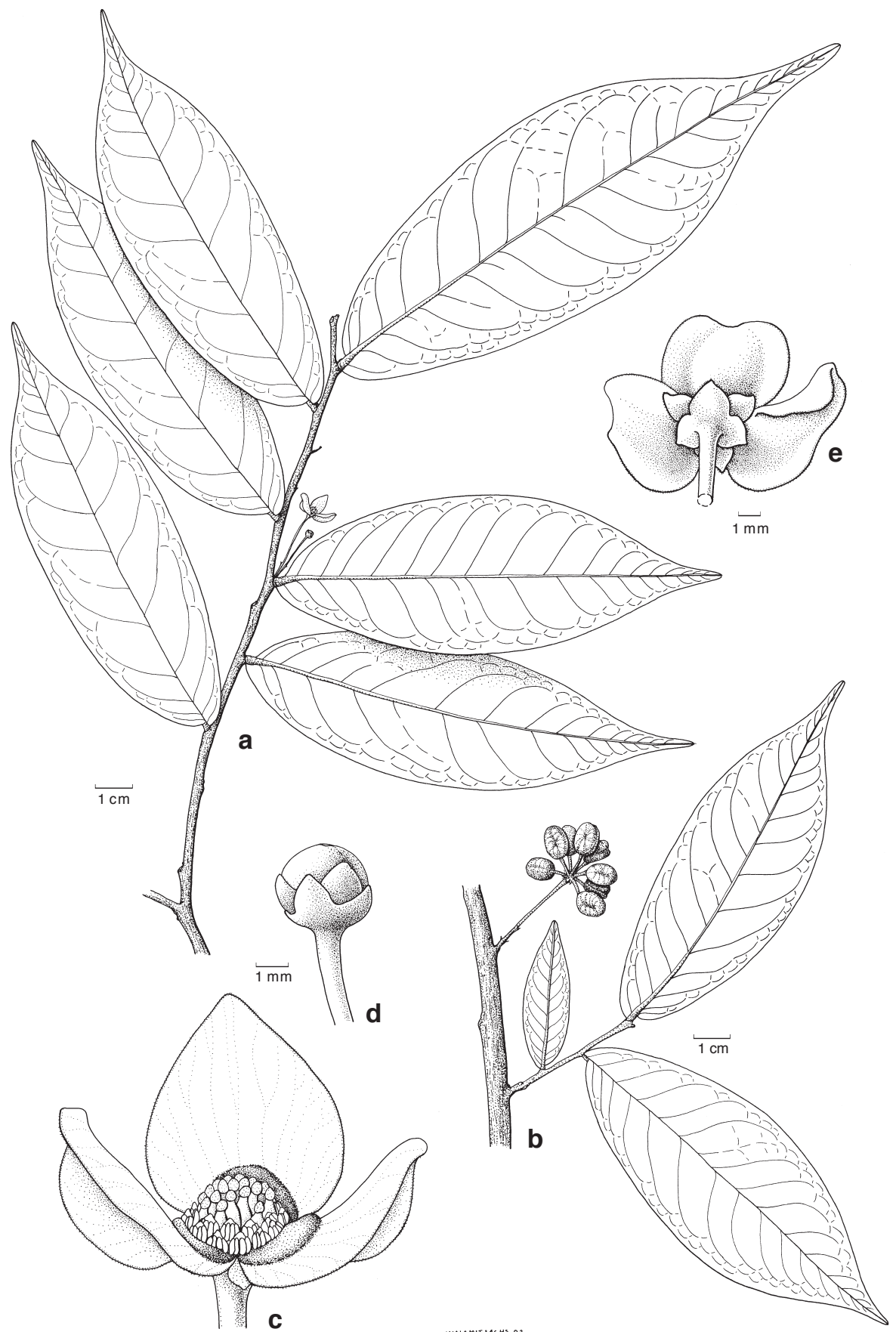

Fig. 2. Miliusa amplexicaulis Ridl. a. Flowering branch; b. fruiting branch; c. flower with stamens and carpels exposed; d. flowerbud; e. flower with view on connate sepals (all: Maxwell 87-565). 


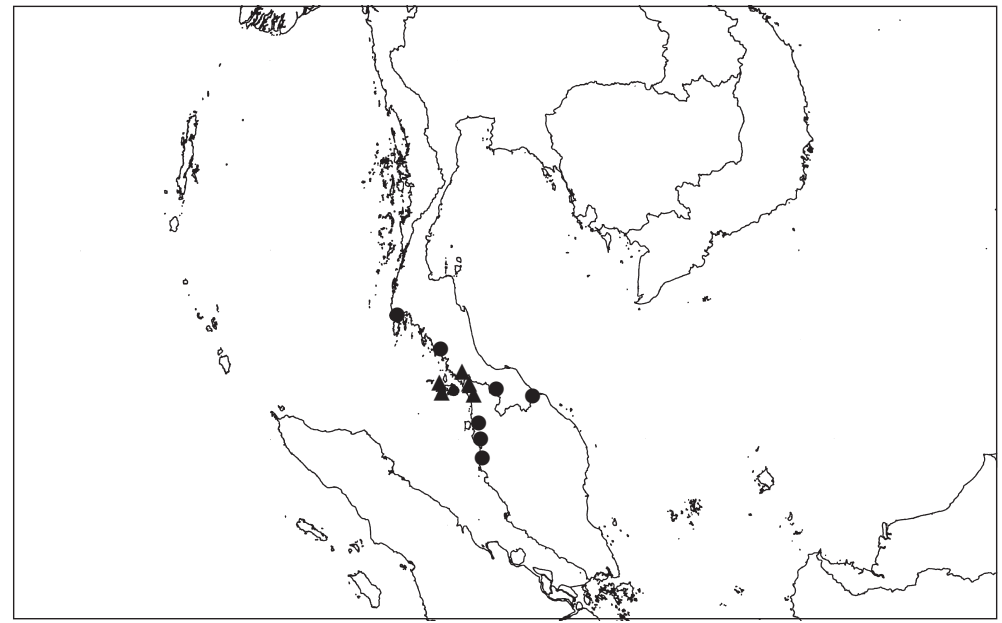

Map 5. Distribution of Miliusa amplexicaulis Ridl. (๑) and M. parviflora Ridl. (ム).

$0.2-0.5$ by $0.2-0.3 \mathrm{~mm}$, glabrous; ovules 1 , basi-lateral. Monocarps $4-15$, subglobose, girdled with central groove when dried, $0.6-0.8$ by $0.4-0.65 \mathrm{~cm}$, apiculation absent; stipe $3-11$ by $0.75-1 \mathrm{~mm}$. Seed 1 , ellipsoid, $5-7$ by $4-5 \mathrm{~mm}$, pericarp $0.5 \mathrm{~mm}$ thick.

Distribution - Thailand, Peninsular Malaysia.

Ecology - Primary, evergreen forest. Soil: Sandstone, limestone. Location: On hills and at the base of cliffs. Abundance: Scarce to rather common. Altitude: 75-250 m. Flowering: February to September; fruiting: February, March, June, July.

Field notes - Outer bark dark brown. Leaves green. Peduncle green. Pedicel green. Bracts green. Bracteoles green. Sepals green. Outer petals green. Inner petals light green when young, turning pale greenish yellow, upper part of glandular tissue brown, lower part creamish light green. Stamens cream. Theca yellow. Carpels brown. Stigma tan. Monocarps creamish light green turning dark purple. Stipe creamish light green turning dark purple.

\section{Miliusa brahei (F. Muell.) Jessup - Fig. 3; Map 6}

Miliusa brahei (F. Muell.) Jessup (1986) 227; (1988) 520. - Saccopetalum brahei F. Muell. (1874) 159. - Type: Fitzalan s.n. (holo MEL 234172; iso BRI n.v., K n.v., NSW), Australia, Queensland, North Kennedy, near Port Denison, 1874, fl.

Deciduous treelets or trees, 5-30 m tall, dbh $15-50 \mathrm{~cm}$. Twigs strigose or tomentose, glabrescent. Petioles $1-3.5$ by $0.5-1.5 \mathrm{~mm}$. Leaves (broadly) elliptic to ovate, $2.5-13.5$ by $1-5.5 \mathrm{~cm}, 1 / \mathrm{w}$ ratio $(1.9-) 2.2-2.9(-3.4)$, base acute, seldom obtuse or rounded, apex acute to acuminate $(-1.5 \mathrm{~cm})$, lamina above glabrous, below (densely) strigose to tomentose, midrib above flat or slightly raised, secondary veins 7-11 pairs with sometimes intersecondary veins, angle with midrib $20-55^{\circ}$, angles generally bigger at the base. Cymes in axils of fallen leaves, 1 - or 2-flowered; peduncles $0-5(-7)$ by $0.5-1 \mathrm{~mm}$; pedicels (13-)27-67(-84) by $0.33-0.75 \mathrm{~mm}$; bud scales $1-3$ by $1-2 \mathrm{~mm}$; bracts absent; 


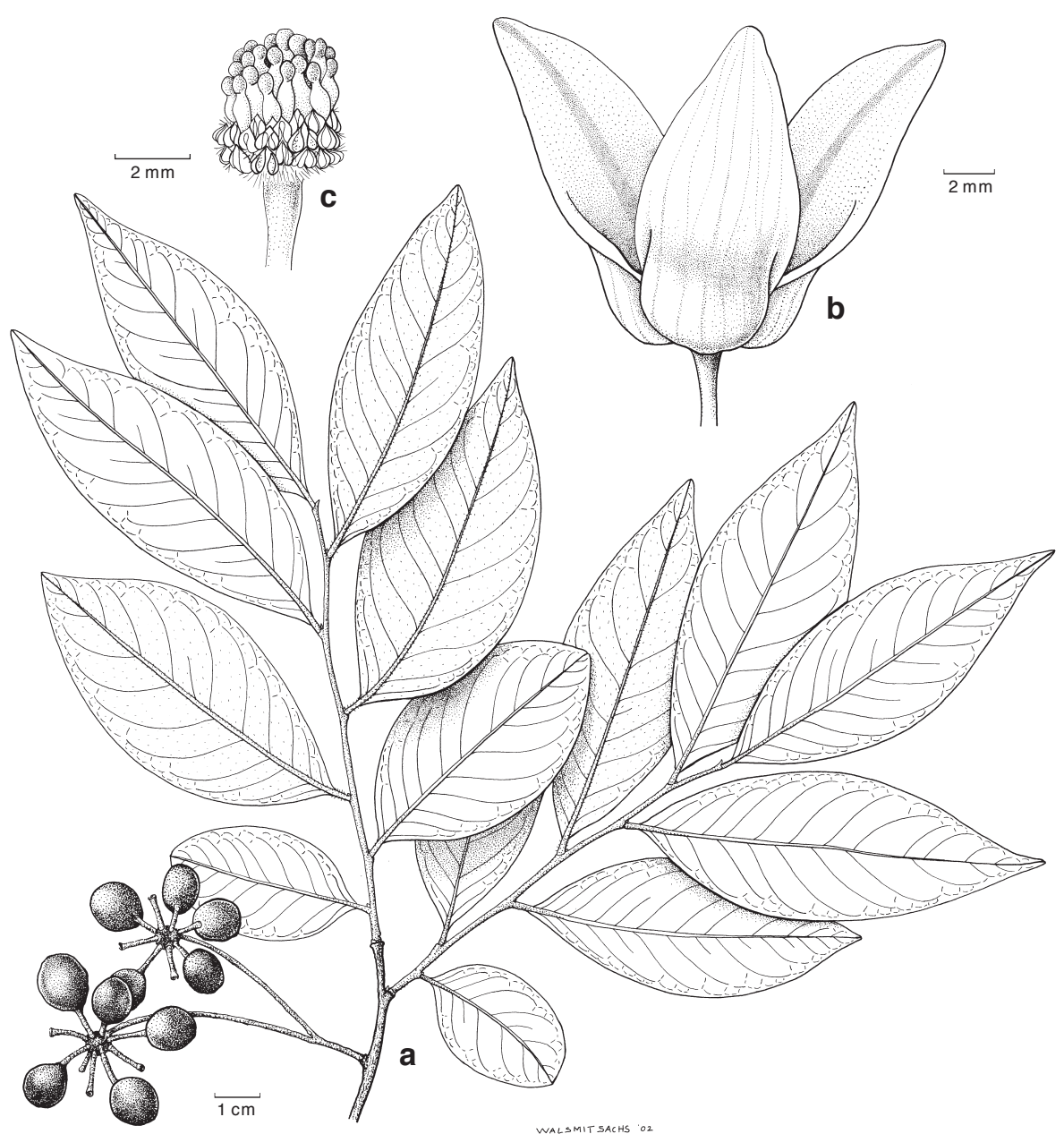

Fig. 3. Miliusa brahei (F. Muell.) Jessup. a. Fruiting branch; b. flower; c. flower with tepals removed (a: Lyons 58; b, c: Sankowsky 701).

bracteoles 2, first bracteole triangular, $0.5-1.5$ by $0.5 \mathrm{~mm}$, apex not recurved, placed just above base of pedicel; second bracteole narrowly triangular, $0.5-0.7$ by $0.3-0.5$ $\mathrm{mm}$, apex not recurved, placed c. 0.5 to $1.5 \mathrm{~cm}$ from base of pedicel, caducous. Sepals broadly triangular, free, $1-2$ by $1-1.3 \mathrm{~mm}$, veins 3 visible inside, not persisting when fruiting. Outer petals boat-shaped, $1.5-2.8$ by $0.2-0.5 \mathrm{~mm}$, apex not curved, veins not visible. Inner petals ovate, $0.6-1.4$ by $0.4-0.8 \mathrm{~cm}, 0.5 \mathrm{~mm}$ thick, sac $2-3$ by $3-5 \mathrm{~mm}$, apex obtuse, margins not recurved, outside strigose, inside glabrescent except margins white pubescent, veins not visible, glandular tissue visible. Torus hemispherical, 1.5-2 by $2-2.3 \mathrm{~mm}$. Stamens $25-37,0.75-1.25$ by $0.6-1.3 \mathrm{~mm}$, connective prolongation obtuse; staminodes absent. Carpels 21-27, round flask-shaped, 1-1.8 by $0.5-1 \mathrm{~mm}$, strigose; stigma capitate to club-shaped, $0.5-0.8$ by $0.3-0.5 \mathrm{~mm}$, glabrous; ovules $5-7$, 


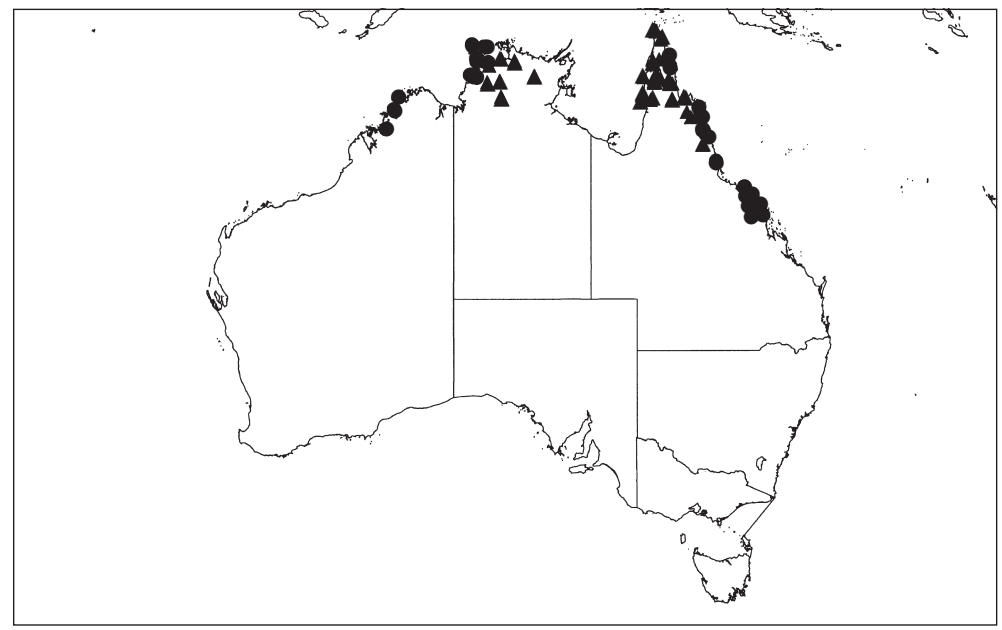

Map 6. Distribution of Miliusa brahei (F. Muell.) Jessup and M. traceyi Jessup (A).

lateral, biseriate. Monocarps 2-16; globular or elliptic to irregular, $0.5-1.6$ by $0.6-1.1$ cm; stipe 3-21 by $1-1.5 \mathrm{~mm}$, apiculation not present. Seeds $1-6$, elliptical to elliptical with one side flattened, $4-11$ by $4-11 \mathrm{~mm}$; pericarp $0.5 \mathrm{~mm}$ thick.

Distribution - Northern Australia.

Ecology - Monsoon to semi-deciduous forest, sometimes in understorey. Soil: Sand, loam, red soil, granite outcrops, peat. Location: Near beach, streams, coastal dunes or inundated areas. Abundance: Rare to fairly dense. Altitude: 0-100 m. Flowering: September to December; fruiting: January, March, September, November, December.

Field notes - Outer bark light grey to dark brown, fissured, tessellated to flaky. Inner bark fragrant. Sapwood orange yellow to fawn yellow to creamish. Leaves glossy. Sepals (olive) brown. Inner petals yellow-green with red discoloration. Monocarps glossy dark purple to black when mature.

\section{Miliusa horsfieldii (Benn.) Pierre - Fig. 4; Map 1}

Miliusa horsfieldii (Benn.) Pierre (1881) t. 38. - Saccopetalum horsfieldii Benn. (1840) 165, t. 35. - Type: Horsfield s.n. (holo BM 554019; iso BM, K), Indonesia, Java, Prov. Banyumas, 1814 , fl.

Saccopetalum arboreum Elmer (1913) 1739, syn. nov. - Miliusa arborea (Elmer) J. Sinclair (1955) 378. - Type: Elmer 12677 (lecto A, designated here; iso B, BM, BO, E, G, L, NSW, NY, P, U, US, Z), Philippines, Palawan, Brooks Point, Addison Peak, February 1911, fl.

Miliusa tectona C.E. Parkinson (1923) 75, syn. nov. - Saccopetalum tectonum (C.E. Parkinson) Chatterjee (1948) 59. - Type: Parkinson 545 (holo K; iso DD n.v.), India, Andaman Islands, Middle Andaman, May 1915, fl.

Saccopetalum lineatum Craib (1924) 82, syn. nov. - Miliusa lineata (Craib) Ast (1938) 120. - Type: Kerr 6012 (holo K; iso BM, CAL, E), Thailand, Nakawn Sawawn, Mê Wong, May 1922, fl.

Saccopetalum unguiculatum C.E.C. Fisch. (1926) 454, syn. nov. - Miliusa unguiculata (C.E.C. Fisch.) J. Sinclair (1955) 378. - Type: Parkinson 1694 (holo K; iso ABD, K), Burma, S. Tenasserim, Naungbwa, Theinkun Chaung, fl. 
Alphonsea prolifica Chun \& F.C. How (1958) 1, syn. nov. - Saccopetalum prolificum (Chun \& F.C. How) Tsiang in Tsiang \& Li (1964) 380. - Miliusa prolifica (Chun \& F.C. How) P.T. Li (1993) 315, syn. nov. - Alphonsea mollis Merr. \& Chun (1935) 230, nom. illeg., non Dunn - Type: How 70951 (holo IBSC n.v.; iso A, B, K, NY, P),China, Hainan, Yai Hsien, Lofung, July 1933, fr.

Deciduous treelets or trees, 2-35 m tall, dbh $25-60 \mathrm{~cm}$. Twigs (densely) pilose, glabrescent. Petioles $1-5$ by $0.8-2.5 \mathrm{~mm}$. Leaves (narrowly) ovate, seldom obovate, $5.5-22$ by $2-8 \mathrm{~cm}, 1 / \mathrm{w}$ ratio (1.9-) $2.4-3.7(-4)$, base always unequal, acute to rounded, slightly emarginate, apex acute to slightly cuspidate $(-3.5 \mathrm{~cm})$, lamina (densely) pilose, glabrescent, midrib above flat to sunken, secondary veins $8-13$ pairs with intersecondary veins, angle with midrib $40-60^{\circ}$, angles generally bigger at the base. Cymes often in axils of fallen leaves, seldom in axils of mature leaves, 1- or 2-flowered; peduncles $1-7$ by $0.7-1 \mathrm{~mm}$; pedicels $2-20(-54)$ by $0.7-1 \mathrm{~mm}$; bud scales $1-3.5$ by $1.5-2.5(-4)$ $\mathrm{mm}$; bracts absent; bracteoles 2, first bracteole triangular, $2-3.5$ by $1 \mathrm{~mm}$, apex not recurved, placed just above base of pedicel, caducous; second bracteole (narrowly) triangular, $1-3$ by $0.7-1 \mathrm{~mm}$, apex not recurved, placed halfway pedicel, caducous. Sepals tongue-shaped to broadly triangular, free, $2.5-7(-10)$ by $1-2 \mathrm{~mm}$, margins slightly incurved, veins $6-8$, persisting longer than outer petals. Outer petals narrowly tongue-shaped, truncate, $3.5-13$ by $1-2 \mathrm{~mm}$, apex not curved, margins incurved, veins 6 or 7 . Inner petals (broadly) triangular, $1.7-4$ by $0.5-1.5 \mathrm{~cm}, 0.5 \mathrm{~mm}$ thick, sac $2-5$ by $4-11 \mathrm{~mm}$, apex acute, margins somewhat incurved at anthesis, outside pilose to tomentose, dense near margins and base, inside margins and apex pubescent, veins 9 or 10 with some reticulation, glandular tissue visible. Torus elongated hemispherical to sometimes rounded, $2-3$ by $2-2.5 \mathrm{~mm}$. Stamens $40-65,0.7-1.3$ by $0.5-1 \mathrm{~mm}$, connective prolongation obtuse; staminode(s) $0-5(-11), 0.5-1$ by $0.3-0.7 \mathrm{~mm}$, sometimes with underdeveloped anthers. Carpels 17-45, round flask-shaped, 1-1.7 by $0.5-0.8$ $\mathrm{mm}$, sparsely strigose to glabrous; stigma capitate or club-shaped, $0.3-0.8(-1)$ by 0.3-0.5 mm, glabrous; ovules 6-10, lateral, biseriate. Monocarps 5-20, subglobular to almost globular or elliptic, $1-2.3$ by 1-1.9 cm, apiculation not present; stipe (3-)8-24 by $1-2 \mathrm{~mm}$. Seeds $2-5(-8)$, elliptical with one or two sides flattened, 6-9(-12) by 4-8(-12) mm, pericarp 1-4 mm thick.

Distribution - China (Hainan, Guangdong), Myanmar, Thailand, Laos, Nicobar and Andaman Islands, Peninsular Malaysia, Indonesia, Philippines, Australia.

Ecology - Semi-deciduous forest, sometimes in understorey. Soil: Alluvial, chalk, clay, sand; rocky; very fertile moist humus. Location: On sloping land to steep slopes; along creeks, gullies, streams, riverine areas. Abundance: infrequent to very common. Altitude: 0-250 m. Flowering: Throughout the year (depending on location); fruiting: Throughout the year.

Field notes - Sometimes with buttresses. Outer bark $2 \mathrm{~mm}$ thick, grey to black, flaky, smooth, fissured, stripes 1-2 cm wide. Inner bark 4-15 mm thick, cream to pale brown, layered. Sapwood yellow (brown) to white, moderately hard, without odour or taste. Leaves dark green, glossy above. Peduncle yellowish green. Pedicel yellowish green. Flowers with nectar on the midrib inside. Sepals green. Outer petals green. Inner petals green to greenish yellow when young, outside green with faint tinge of red, inside mottled red or brownish with red brown midrib when mature. Stamens (greenish) yellow. Carpels green to greenish yellow. Stigmas soon turning brown. 


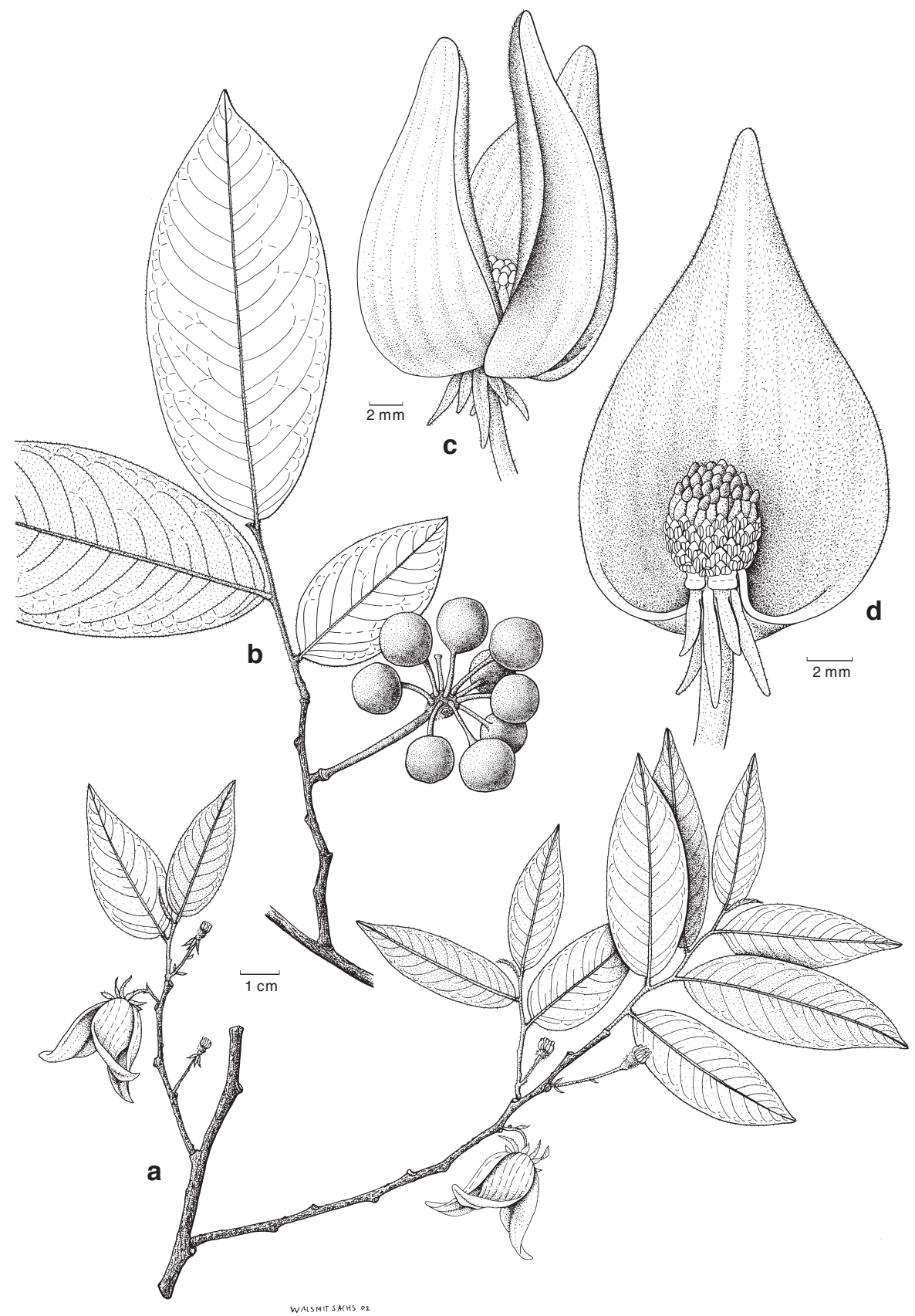

Fig. 4. Miliusa horsfieldii (Benn.) Pierre. a. Flowering branch; b. fruiting branch; c. flower; d. flower with two inner petals removed (a, c, d: Jessup 644; b: Geesink et al. 6952). 
Vernacular names - Kalak (Java); Djanglot (Java); Welaga (Sulawesi: Muna); Kwanjitan (Bali); Banitan (Java); Waymana, Elu (Mangoli (Sula)); Haloeta (Gorontalo or Laluta); Toka tomuhu (Samuja (Kadai)); Hararo (Tobelo); Balai (Lampongs); Kaju Pantis (Kalianda); Pantis Kuning (Kaj.); Ubaran (Palawan); jungle Saguan (Hindi); I rêt (Thai).

Note - Tsiang (in Tsiang \& Li, 1964) cited the flowering specimen How 71794 as type specimen, which was not the type indicated by Chun and How. For this reason Li (1993) called Saccopetalum prolificum homotypic with Alphonsea prolifica.

\section{Miliusa koolsii (Kosterm.) J. Sinclair - Fig. 5; Map 3}

Miliusa koolsii (Kosterm.) J. Sinclair (1955) 378. - Saccopetalum koolsii Kosterm. (1952) 459. - Type: Kostermans 430 (holo BO; iso B, L), Indonesia, New Guinea, Manokwari, Warnapi, 15 km north of Ransiki, September 1948, fl.

Deciduous treelets or trees, (6-)24-40(-55) m tall, dbh (10-)36-50 cm. Twigs (sparsely) strigose, glabrescent. Petioles $1-5$ by $0.7-2 \mathrm{~mm}$. Leaves elliptic to (narrowly) ovate, $6-22$ by $2-10 \mathrm{~cm}, 1 / \mathrm{w}$ ratio $(1.8-) 2.3-3.3$, base seldom unequal, acute to slightly cuneate or rounded, apex acute to acuminate $(-1.5 \mathrm{~cm})$, lamina above glabrous, below (sparsely) strigose, glabrescent, midrib above sunken with edges slightly raised, secondary veins 7-9 pairs with intersecondary veins not very obvious, angle with midrib $30-50^{\circ}$, angles generally smaller at the base. Cymes axillary or terminal, 1-3(-4)-flowered; peduncles $1-6$ by $0.5-1 \mathrm{~mm}$; pedicel $9-25(-45)$ by $0.3-0.5 \mathrm{~mm}$; bud scales $0.7-2$ by $1.2-2(-3) \mathrm{mm}$; bract(s) $1-4$, triangular, $0.6-1.3$ by $0.3-0.8 \mathrm{~mm}$, apex not recurved, caducous; bracteole 1 , triangular, $0.2-0.5$ by $0.2-0.5 \mathrm{~mm}$, apex not recurved, placed c. 1/3 to $1 / 2$ from base of pedicel, caducous. Sepals triangular, free, $1-1.5$ by $0.5-1 \mathrm{~mm}$, midrib darkened in dried material, persisting longer than outer petals. Outer petals boat-shaped, $1.5-2.5$ by $0.3-0.7 \mathrm{~mm}$, apex not curved, midrib thicker. Inner petals ovate, $0.9-1.2$ by $0.4-0.7 \mathrm{~cm}, 0.5 \mathrm{~mm}$ thick, sac (1-)3-4 by 2-4 mm, apex obtuse, margins not recurved, outside strigose, inside glabrous except margins pubescent, veins 8-10, glandular tissue visible, sometimes dilates late close to the base. Torus hemispherical, $1-2$ by $1-2$ mm. Stamens $24-38,0.7-1.3$ by $0.6-1.3$ $\mathrm{mm}$, connective prolongation obtuse; staminode(s) $0-4,0.5-1$ by $0.5-0.8 \mathrm{~mm}$, always with underdeveloped anthers. Carpels $10-13$, flask-shaped, 1-2 by (0.3-)0.6-0.8 $\mathrm{mm}$, densely to scattered strigose; stigma club-shaped to elongated capitate, $0.5-1$ by 0.2-0.5 mm, glabrous; ovules 8-12, lateral, biseriate. Monocarps 2-11, globular to semi-elliptic to elliptic, $1.5-4.3$ by $(1.3-) 2-3.2 \mathrm{~cm}$; stipe (11-) $16-29$ by $1.5-4 \mathrm{~mm}$, apiculation not present. Seeds 1-9, wedge-shaped to elliptical, sometimes with sides flattened, 11-17 by 7-15 $\mathrm{mm}$; pericarp $1.5-7 \mathrm{~mm}$ thick.

Distribution - Indonesia (Papua) and Papua New Guinea.

Ecology - Primary forest or old secondary forest. Soil: Clay, stone. Location: Flat areas, near flood plains or rivers well above flood line. Abundance: Rather scarce to common. Altitude: 0-400 m. Flowering: May, June, July, September; fruiting: June to October.

Field notes - Sometimes with buttresses. Branches purplish. Outer bark 0.5-1 mm thick, dark grey to black, many shallow, narrow fissures, flaky. Inner bark 5-12 mm thick, light to straw brown-white. Sapwood yellowish white, hard. Heartwood red-brown or like sapwood. Inner petals green to pinkish. 


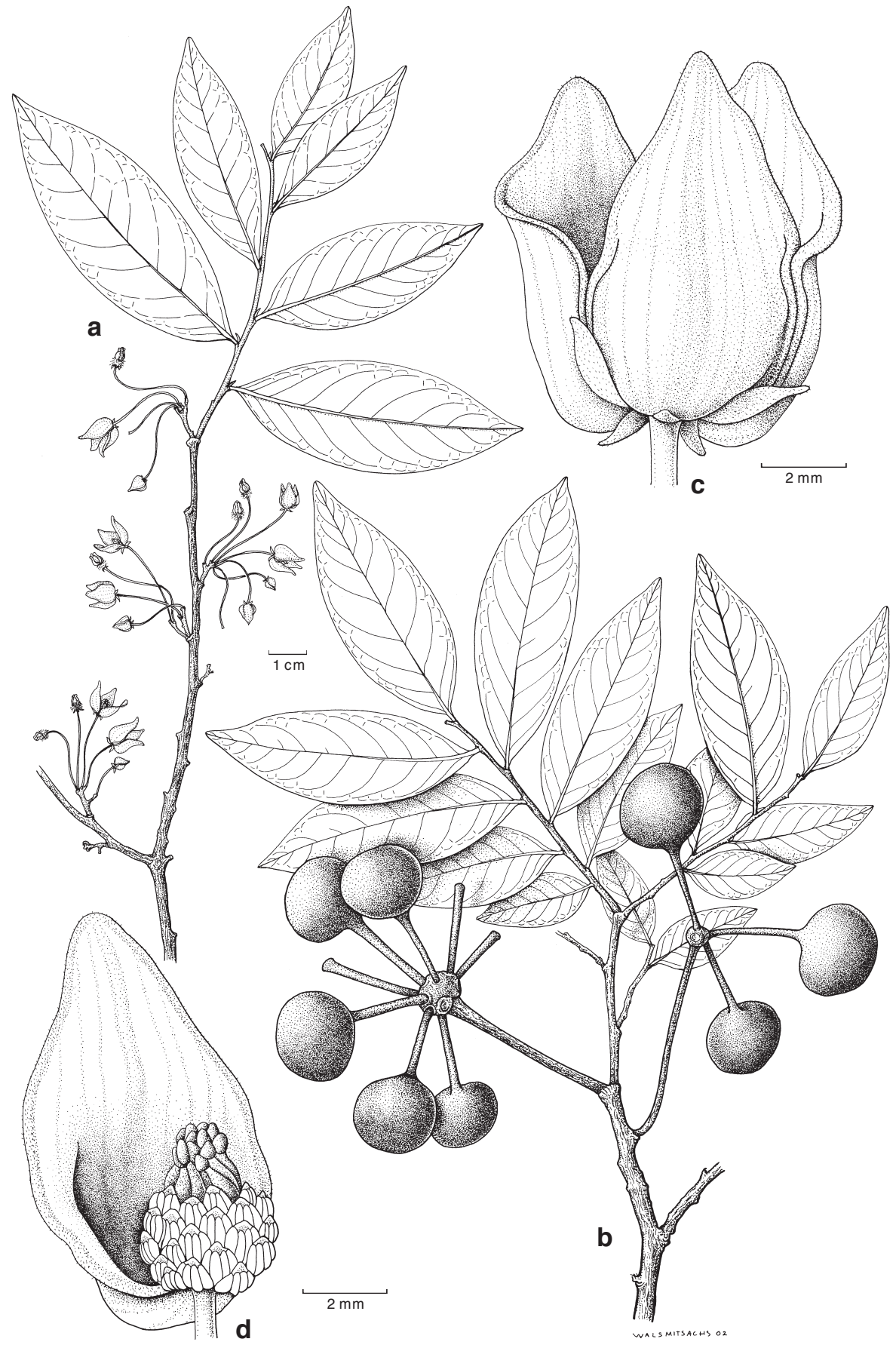

Fig. 5. Miliusa koolsii (Kosterm.) J. Sinclair. a. Flowering branch; b. fruiting branch; c. flower; d. flower with two inner petals removed (a, c, d: Carr 16518; d: NGF 28031 (Henty)). 
Vernacular names - Kolien, Kolie, Kobin (Mooi); Broeboeseroe (Kemtoek), Mies, Miehs, Miesmoek (Atam, Hattan, Manikiong); Ndau (Atam); Gorambusan (Kaigorin); Gadik (Rawa); Salisalin (Mawan); Oli-Oli (Karia).

\section{Miliusa longipes King - Fig. 6; Map 7}

Miliusa longipes King (1893) 124. - Type: King 7352 (holo CAL n.v.; iso BM, BO, G, L, WU), Malaysia, Peninsular Malaya, Perak, Larut, March 1885, fl.

Miliusa smithiae Craib (1923) 44, syn. nov. - Type: Smith 684 (holo K; iso BM), Thailand, Nakawn Sritamarat, Khao Ram, March 1922, fl.

Evergreen shrubs or treelets, $1.5-9 \mathrm{~m}$ tall, dbh 2-10(-20) cm. Twigs sparsely strigose, glabrescent. Petioles $1-5$ by $1-2 \mathrm{~mm}$. Leaves (narrowly) ovate to sometimes elliptic, $5-22.5$ by $2-8 \mathrm{~cm}, 1 / \mathrm{w}$ ratio $(1.8-) 2.4-3.5(-4.1)$, base (slightly to broadly) cuneate seldom acute or rounded, apex acuminate to slightly cuspidate $(-2.5 \mathrm{~cm})$, lamina glabrous, midrib above flat or slightly sunken with edges slightly prominent, secondary veins $8-13$ pairs seldom with strong intersecondary veins, angle midrib $35-60^{\circ}$, angles generally smaller at the base. Cymes axillary, 1-flowered; peduncles $0-4$ by $0.5-1 \mathrm{~mm}$; pedicels $8-69$ by $0.3-0.8 \mathrm{~mm}$; bud scales absent; bract(s) $1-4$, triangular, concave, $0.5-1.3$ by $0.5-1 \mathrm{~mm}$, apex recurved; bracteole 1 , triangular, concave, $1-1.5$ by $0.5-1$ $\mathrm{mm}$, placed $0-0.5 \mathrm{~cm}$ from base of pedicel, apex recurved, sometimes persisting when fruiting. Sepals broadly triangular, $1-2$ by $0.7-1.5 \mathrm{~mm}$, midrib visible inside, often persisting when fruiting. Outer petals broadly triangular, $1.5-2.5$ by $0.7-1.5 \mathrm{~mm}$, apex not curved, midrib visible inside. Inner petals ovate, $0.7-1.9$ by $0.3-0.8 \mathrm{~cm}$, $0.3-0.5 \mathrm{~mm}$ thick, sac $1-2.5$ by $1-2.5 \mathrm{~mm}$, apex obtuse, reflexed at anthesis, margins reflexed at anthesis, outside sparsely strigose to glabrous, inside glabrous except margins pubescent, veins 5 with some reticulation, glandular tissue not always visible. Torus hemispherical to subglobular, $1-2$ by $1-1.5 \mathrm{~mm}$. Stamens $18-27(-36), 0.7-1.2$ by $0.5-1 \mathrm{~mm}$, connective prolongation obtuse; staminode(s) $0-4,0.5-1$ by $0.2-0.5$

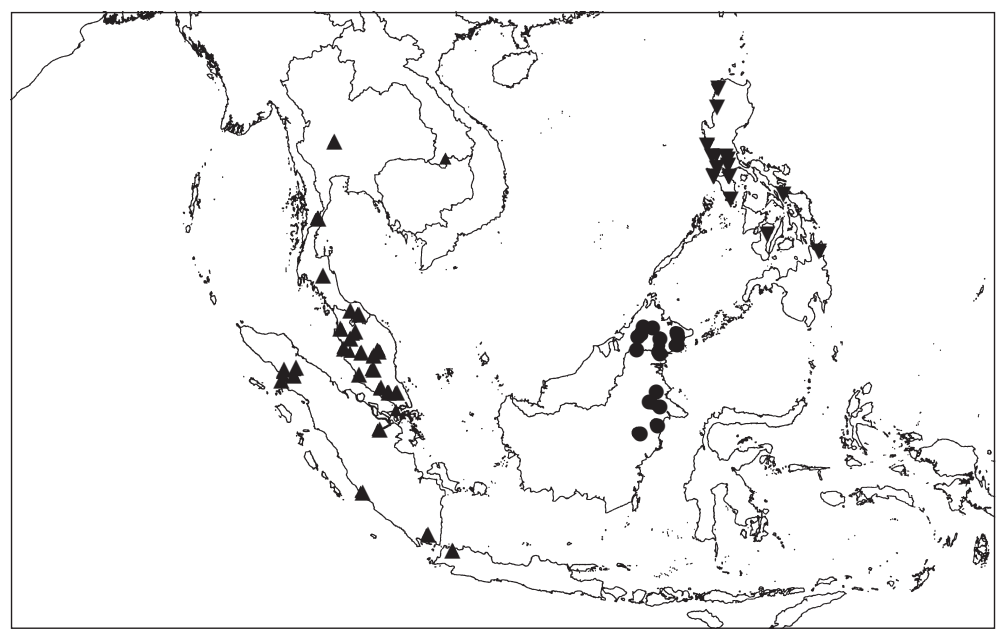

Map 7. Distribution of Miliusa longipes King (\), M. macropoda Miq. (•) and M. vidalii J. Sinclair (V). 


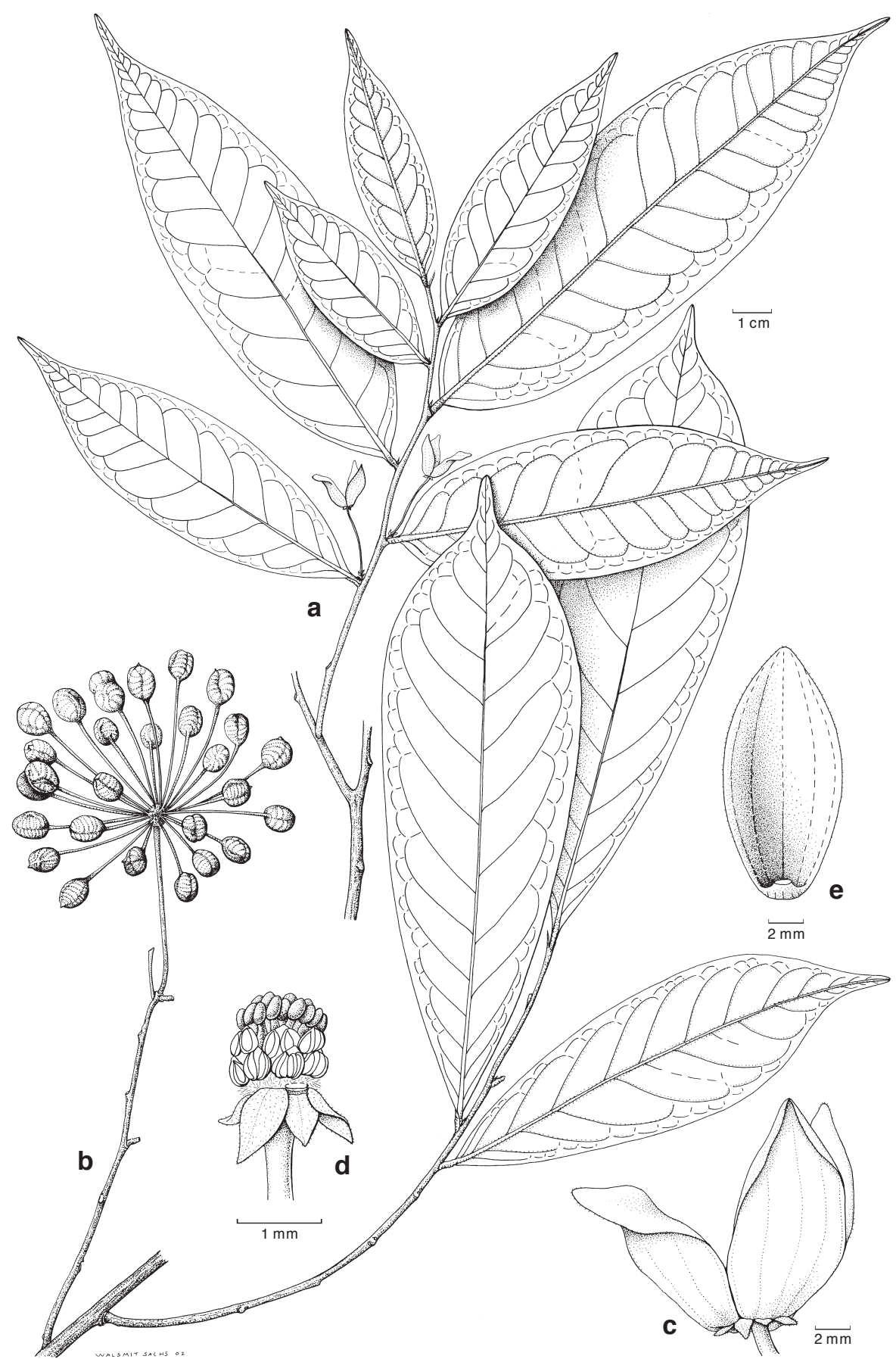

Fig. 6. Miliusa longipes King. a. Flowering branch; b. fruiting branch; c. flower; d. flower with inner petals removed; e. inner petal (a, c-e: SF 35049 (Kiah); b: KEP/FRI 14790 (Suppiah)). 
$\mathrm{mm}$, with underdeveloped anthers. Carpels $10-48$, flask-shaped, $0.7-1.3$ by $0.3-0.7$ $\mathrm{mm}$, scattered strigose; stigma capitate to slightly club-shaped, $0.3-0.8$ by $0.3-0.5$ mm, glabrous; ovules 2, lateral, uniseriate. Monocarps 5-31, elliptic to globular or irregular shaped, $0.7-1.3$ by $0.5-1.1 \mathrm{~cm}$; stipe $18-30(-43)$ by $1-2 \mathrm{~mm}$, apiculation not present. Seed $(s) 1$ (or seldom 2), elliptical or elliptical with one side flattened, 6-9 by $4-7 \mathrm{~mm}$, pericarp $0.5 \mathrm{~mm}$ thick.

Distribution - Thailand, Laos, Peninsular Malaysia, Singapore, Sumatra, Java.

Ecology - Evergreen or riverine forest. Soil: Rocky, limestone, loam. Location: On hills, plateaus or flat land; near streams, riversides. Abundance: Scattered to common. Altitude: 0-600 m. Flowering: March to May, July to November; fruiting: January to March, May to November.

Field notes - Taproot black. Outer bark greenish grey, smooth. Inner bark brownish. Sapwood yellowish. Leaves dark green, glossy, papery. Pedicels green. Sepals green to pink with red tip. Outer petals green to pink with red tip. Inner petals outside yellow, inside dark cream with dark red or maroon vertical midstreak near base. Stamens creamy yellow. Stigmas brown. Monocarps when mature red to black. Stipe bright red.

Vernacular names - Kenerak, Pisang Pisang, Hujan Panas (Malay); Chagau, Chagau Ro-eng (Temuan); Tjantjaraton (Sundanese); Jelaweh (Sakai).

\section{Miliusa macropoda Miq. - Fig. 7; Map 7}

Miliusa macropoda Miq. (1865) 40. - Type: Korthals s.n. (lecto L 0048580, designated here; iso B, L 0048579, L 0048581, L 0048587), Indonesia, Borneo, G. Baluran, fr. \& fl.

Evergreen treelets or trees, (4.5-)7-27(-36) m tall, dbh (5-)12-45 cm. Twigs (densely) strigose or tomentose, glabrescent. Petioles $1-4$ by 1-3 mm. Leaves (broadly) elliptic to ovate, $4.5-23$ by $2.5-9 \mathrm{~cm}, 1 / \mathrm{w}$ ratio $(1.9-) 2.3-3.2(-4.2)$, base unequal, acute to rounded, sometimes emarginate, apex acuminate $(-2.5 \mathrm{~cm})$, lamina sparsely strigose, glabrescent, midrib above flat or slightly sunken, secondary veins 6-12 pairs with sometimes intersecondary veins, angle with midrib $30-60^{\circ}$, angles generally bigger at the base. Cymes extra-axillary, 1- (or 2-)flowered; peduncles 7-25 by $1 \mathrm{~mm}$; rachis $0-4$ by $1 \mathrm{~mm}$; pedicels $55-330$ by $0.7-1.5 \mathrm{~mm}$; bud scales absent; bract 1 , triangular, $1-2$ by $0.7-1 \mathrm{~mm}$, apex not recurved, persisting when fruiting; bracteole 1 , triangular, $1-1.5$ by $0.5-0.7 \mathrm{~mm}$, apex not recurved, placed at c. $1 / 3$ to $1 / 2$ from base of pedicel, sometimes persisting when fruiting. Sepals broadly triangular, free, $1.2-1.5$ by $1.2-2$ $\mathrm{mm}$, veins not visible, not persisting when fruiting. Outer petals triangular, 1.5-2.5 by $1-1.5 \mathrm{~mm}$, apex slightly curved, veins not visible. Inner petals ovate, $0.8-1.5$ by $0.5-1 \mathrm{~cm}, 0.5-0.7 \mathrm{~mm}$ thick, sac $3-4$ by $1-1.5 \mathrm{~mm}$, apex obtuse, recurved at anthesis, margins reflexed at anthesis, outside scattered strigose, inside glabrous except margins pubescent, veins 9 or 10, glandular tissue visible. Torus elongated hemispherical, 2 by 2-3 mm wide. Stamens $125-232,1-2$ by $0.7-1 \mathrm{~mm}$, connective prolongation obtuse; staminodes absent. Carpels $50-80$, narrowly flask-shaped, $1.5-2.3$ by $0.4-0.8 \mathrm{~mm}$, scattered to sparsely strigose; stigma capitate to club-shaped, $0.5-1$ by $0.5-1 \mathrm{~mm}$, glabrous or cobwebbed; ovules 5-7(-10), lateral, uniseriate. Monocarps 11-43, subglobose to cylindrical to transversely elliptic, $1-3$ by $0.8-1.2 \mathrm{~cm}$, apiculate (c. $1 \mathrm{~mm}$ ); stipe $15-44$ by $1.5-3 \mathrm{~mm}$. Seed(s) (1-)3-6, elliptical with one or two sides flattened, $5-12$ by $4-8 \mathrm{~mm}$, pericarp $1-1.5 \mathrm{~mm}$ thick. 


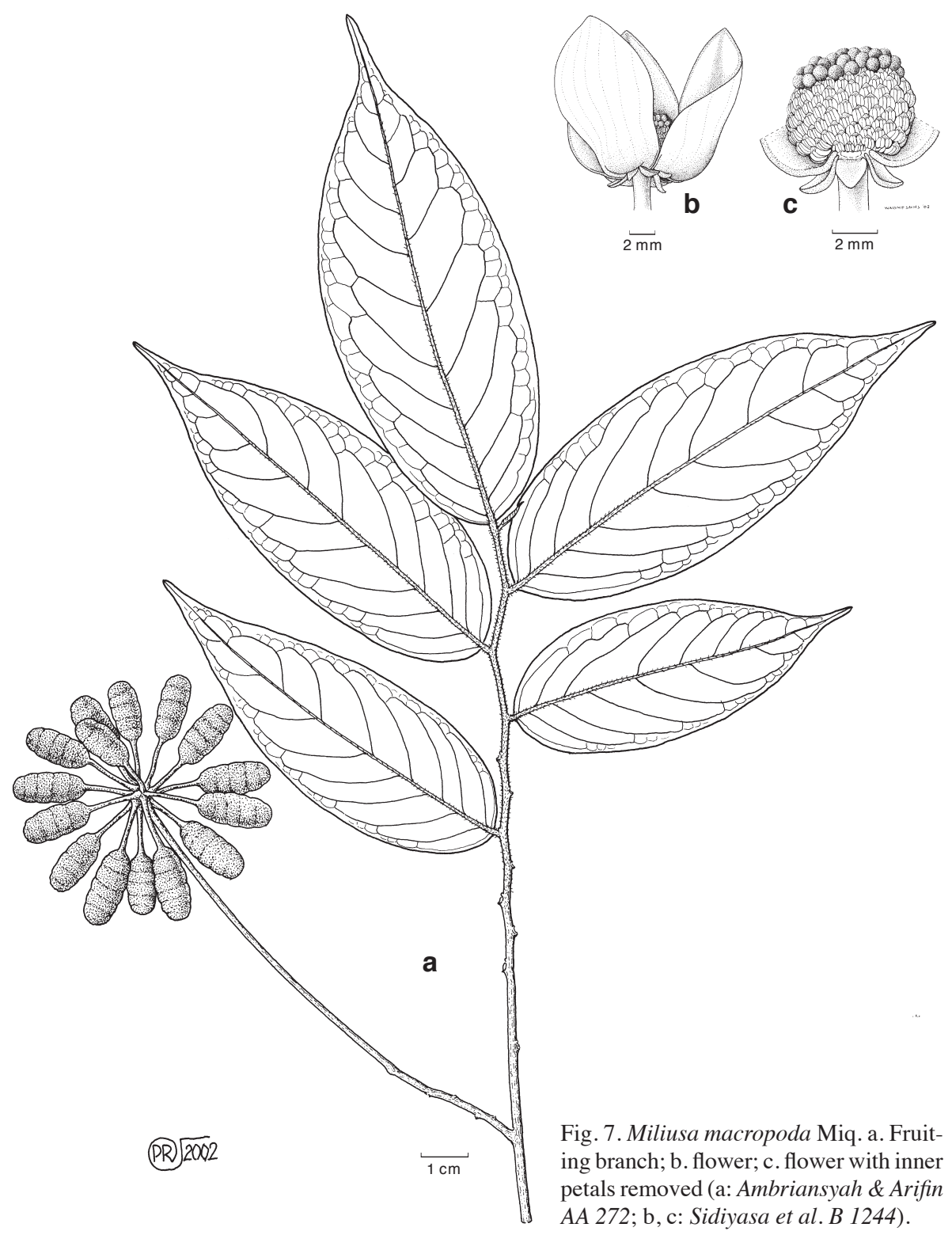

Distribution - Northeast Borneo.

Ecology - Primary or secondary forest. Soil: Sandstone, limestone, loam. Location: Hillsides to low flat country; near riverbanks or in periodically inundated areas. Altitude: $0-400 \mathrm{~m}$. Flowering and fruiting: Throughout the year.

Field notes - Outer bark $0.5 \mathrm{~mm}$ thick, whitish to reddish to blackish, flaky, soft, smooth, lenticelled. Inner bark 5-10 mm thick, yellowish to brown, layered. Sapwood yellow to white, fibrous, hard. Leaves bright green, smooth, shining. Pedicel red. Flowers 
smell like fermented rice. Sepals pinkish. Inner petals greenish when young, yellowish green with purple turning dark purplish brown. Torus yellowish. Stamens greenish white. Monocarps brown green to reddish.

Vernacular names - Malu-Itan (Bassap-Mapulu); Pisang Pisang (Malay); Karai (Sabah).

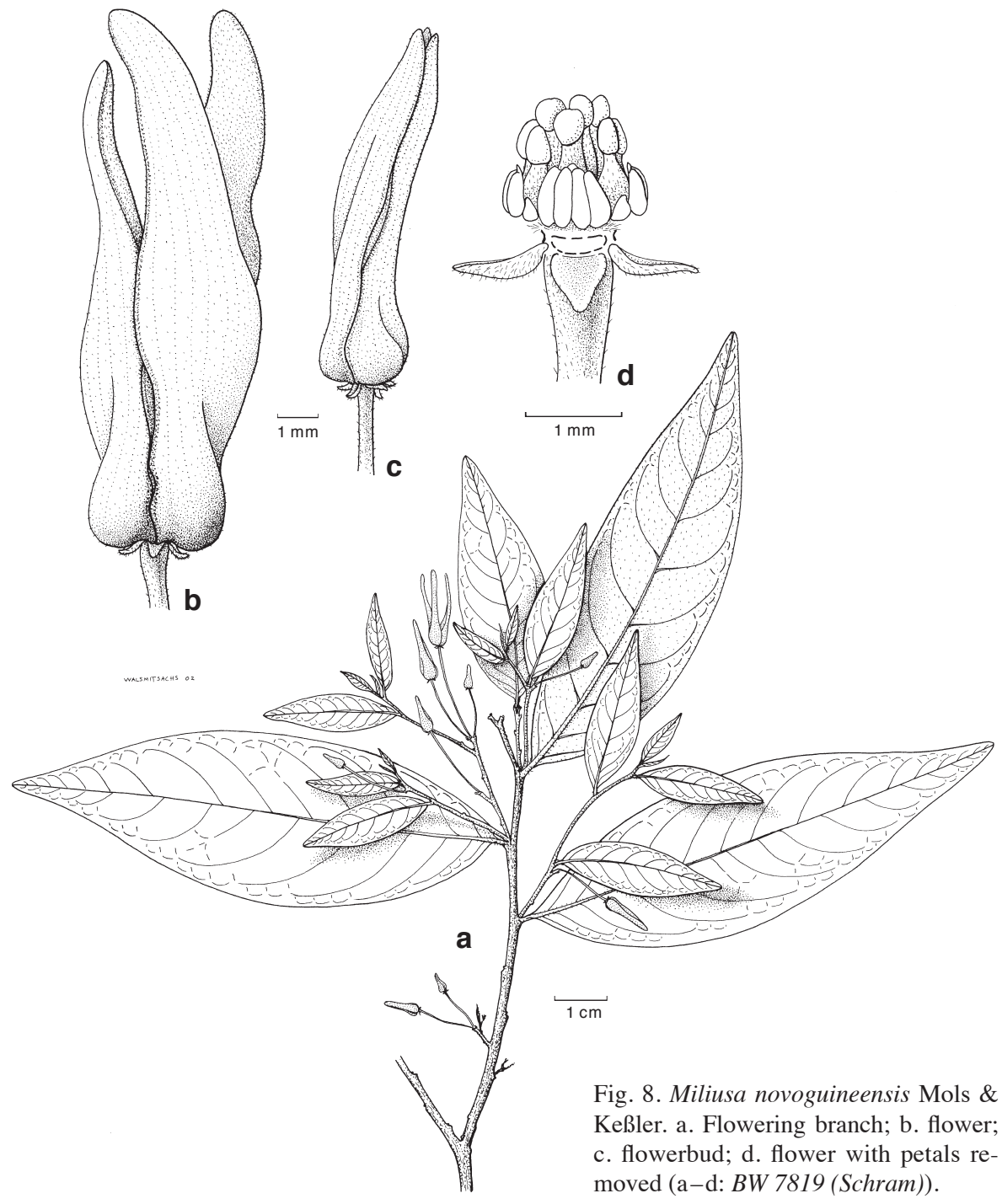

7. Miliusa novoguineensis Mols \& Keßler, spec.nov. - Fig. 8; Map 3

Arbor 18-30 alta, ca. $40 \mathrm{~cm}$ diametro. Ramuli juniores plusminusve pilosi, glabrescentes. Petioli 1-2.5 (-3) cm longi, $0.75-1.25 \mathrm{~cm}$ crassi. Folia elliptica 5-13 cm longa, $2-5.5 \mathrm{~cm}$ lata, apice acuta vel acuminata, basi acuta vel rotundata, costa supra subprominenti, com- 
planata, nervis lateralibus 9-11 paribus. Cymae axillares, 1 vel 2(-5)-floribus, pedunculi $1-5 \mathrm{~mm}$ longi, pedicelli $7-23 \mathrm{~mm}$ longi. Sepala triangulata, $0.6-1.5 \mathrm{~mm}$ longa, $0.5-1 \mathrm{~mm}$ lata. Petala exteriora naviculiformes, $0.8-1.4 \mathrm{~mm}$ longa, $0.2-0.5 \mathrm{~mm}$ lata. Petala interiora anguste usque ovata, $0.8-1.3 \mathrm{~cm}$ longa, $0.1-0.3(-0.4) \mathrm{cm}$ lata, basi sacciformi, $1-2 \mathrm{~mm}$ longe, nervis $6-8$. Stamina $3-9$, staminodia $0-3$, carpella $3-11$, ovulis 2 . - Typus: $B W 7819$ (Schram) (holo L 0048597; iso BO, CANB, LAE), Indonesia, Papua, Div. West New Guinea, Kebar Valley, Anisandau, October 1958, fl.

Deciduous trees, $18-30 \mathrm{~m}$ high; bole $14 \mathrm{~m}$, dbh c. $40 \mathrm{~cm}$. Twigs densely to sparsely pilose, glabrescent. Petioles $1-2.5(-3)$ by $0.75-1.25 \mathrm{~mm}$. Leaves (broadly) elliptic, $5-13$ by $2-5.5 \mathrm{~cm}, 1 / \mathrm{w}(2.1-) 2.4-3.6(-4.4)$, base seldom unequal, acute to rounded, apex acute to acuminate $(-1.5 \mathrm{~cm})$, lamina above glabrous, below (densely) pilose, midrib above slightly sunken or flat, secondary veins 9-11 pairs with intersecondary veins, angle with midrib $45-60^{\circ}$, angles generally bigger at the base. Cymes axillary, seldom extra-axillary, 1-2(-5)-flowered; peduncles $1-5$ by $0.6-1 \mathrm{~mm}$; pedicels $7-23$ by $0.3-0.5 \mathrm{~mm}$; bud scales $0.7-1.5$ by $0.7-1.5 \mathrm{~mm}$; bract 1 , triangular, $0.7-1.5$ by $0.3-0.7 \mathrm{~mm}$, apex not recurved; bracteole 1 , (narrowly) triangular, $0.5-0.7$ by $0.2-0.4 \mathrm{~mm}$, apex not recurved, placed at base to $1 / 3$ from base of pedicel, caducous. Sepals triangular, free, $0.6-1.5$ by $0.5-1 \mathrm{~mm}$, sometimes tissue at base darker, veins not visible, persisting until beginning of fruiting. Outer petals boat-shaped, $0.8-1.4$ by $0.2-0.5 \mathrm{~mm}$, apex not curved, midrib sometimes darker. Inner petals narrowly ovate, $0.8-1.3$ by $0.1-0.3(-0.4) \mathrm{cm}, 0.5 \mathrm{~mm}$ thick, sac $1-2$ by $0.5-1.5 \mathrm{~mm}$, apex obtuse to acute, margins recurved after anthesis, outside (sparsely) strigose, inside strigose with margins pubescent, veins 6-8, glandular tissue not visible. Torus hemispherical, $0.7-1.5$ by $0.7-1.5 \mathrm{~mm}$. Stamens $3-9,0.6-1$ by $0.6-1 \mathrm{~mm}$, connective prolongation obtuse; staminode(s) $0-3,0.3-0.7$ by $0.2-0.5 \mathrm{~mm}$, sometimes with underdeveloped anthers. Carpels $3-11$, flask-shaped, $0.5-1$ by $0.2-0.5 \mathrm{~mm}$, scattered strigose; stigmas (elongated) capitate, $0.2-0.8$ by $0.2-0.5 \mathrm{~mm}$, glabrous; ovules 2; lateral, uniseriate.

Distribution - Indonesia (Papua) and Papua New Guinea.

Ecology - Primary rain forest. Soils: stony, sandy clay. Abundance: Rather scarce to common. Altitude: 30-630 m. Flowering: October and November.

Field notes - Outer bark brown to black, many to few shallow fissures, flaky; inner bark white to cream; sapwood white to yellowish brown; leaves pale green; inner petals yellow.

Vernacular names - Bin or Ben (Kebar).

Note - This species seems closely related to $M$. traceyi from Australia, described by Jessup. The main difference is the number of carpels and stamina, the size of the sepals, outer petals, and the shape of the leaves.

\section{Miliusa parviflora Ridl. - Fig. 9; Map 5}

Miliusa parviflora Ridl. (1911) 65. - Type: Ridley 15340 (holo K; iso BM, SING), Malaysia, Peninsular Malaysia, Perlis, Tebing Tinggi, March 1910, fr, fl.

Semi-deciduous treelets, up to $3 \mathrm{~m}$ tall, dbh up to $6 \mathrm{~cm}$. Twigs tomentose, glabrescent. Petioles $1-2$ by $0.5-1 \mathrm{~mm}$. Leaves elliptic, $4-11.5$ by $1.5-5 \mathrm{~cm}, 1 / \mathrm{w}$ ratio $1.9-3.2$, base often slightly unequal, acute (to rounded), apex acute $(-1 \mathrm{~cm})$, lamina strigose, glabrescent, midrib above slightly sunken, secondary veins 8-14 pairs with no obvious intersecondary veins, veination not distinct, angle with midrib $40-60^{\circ}$, angles 


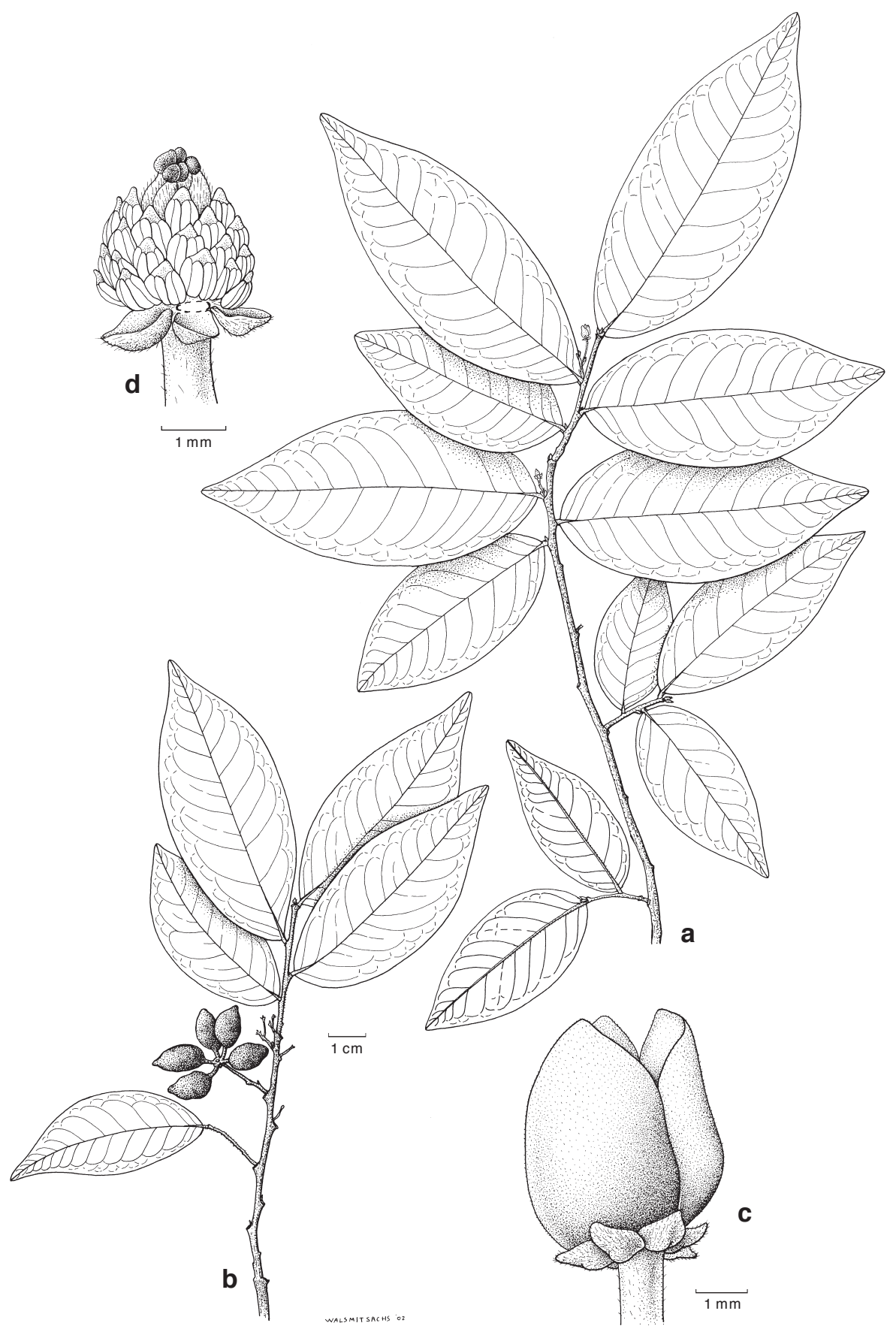

Fig. 9. Miliusa parviflora Ridl. a. Flowering branch; b. fruiting branch; c. flower; d. flower with inner petals removed (a, c, d: Corner s.n. 19-11-1941; b: Ridley 15239). 


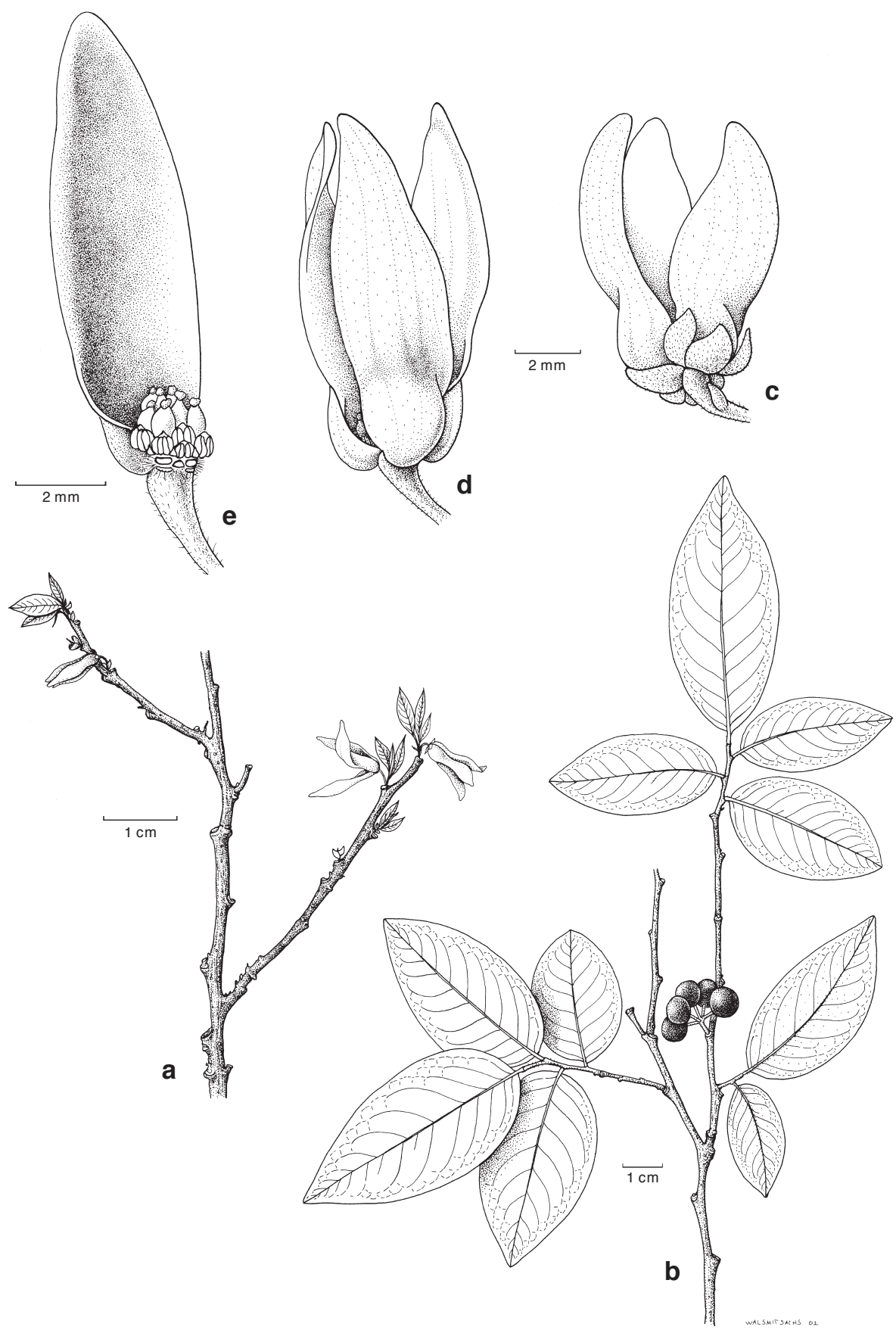

Fig. 10. Miliusa traceyi Jessup. a. Flowering branch; b. fruiting branch; c. flower with view on sepals and outer petals; d. flower; e. flower with two inner petals removed (a, c-e: Leach \& Dunlop 1603; b: Russell-Smith 868). 
generally bigger at the base. Cymes (extra-axillary or) axillary, 1-flowered; peduncles $1.5-2.5(-5)$ by $0.5-0.7 \mathrm{~mm}$; pedicels $5-9$ by $0.5-0.7 \mathrm{~mm}$; bud scales $1-1.5$ by $1 \mathrm{~mm}$; bract 1 , triangular, $0.7-2.5$ by $0.5-0.8 \mathrm{~mm}$, apex not recurved; bracteole 1 , triangular, $0.7-1.5$ by $0.5-0.8 \mathrm{~mm}$, apex not recurved, placed at c. $1 / 3$ to $1 / 2$ from base of pedicel, sometimes persisting when fruiting. Sepals broadly triangular, free, $0.7-1.3$ by $0.7-1.3$ $\mathrm{mm}$, veins not visible, persisting in fruit. Outer petals broadly triangular, 1-1.4 by 0.7-1.3 mm, apex not curved, margins slightly incurved, veins not visible. Inner petals (broadly) ovate, $0.3-0.5$ by $0.2-0.4 \mathrm{~cm}, 0.5 \mathrm{~mm}$ thick, sac not present, apex acute, margins slightly reflexed at anthesis, outside densely strigose, inside margins pubescent, veins 8-10, glandular tissue not visible. Torus elongated hemispherical, 1-1.5 by $0.7-1.5 \mathrm{~mm}$ wide. Stamens $30-40,1-1.5$ by $0.5-0.1 \mathrm{~mm}$, connective prolongation acute; staminodes absent. Carpels $10-13$, flask-shaped, $1.2-2$ by $0.3-0.5 \mathrm{~mm}$, densely strigose; stigma capitate to club-shaped, $0.3-0.5$ by $0.2-3 \mathrm{~mm}$, glabrous; ovules $3-6$, lateral, biseriate. Monocarps $4-8$, ellipsoid, $0.9-1.3$ by $0.6-0.8 \mathrm{~cm}$, (slightly) apiculate (c. $1 \mathrm{~mm}$ ); stipe $2-4$ by $1 \mathrm{~mm}$. Seeds $2-4$, elliptical with one or two sides flattened, 6-9 by $3-4 \mathrm{~mm}$, pericarp $0.5 \mathrm{~mm}$ thick.

Distribution - Thailand and Peninsular Malaysia.

Ecology - Primary evergreen forest. Soil: Limestone. Location: Shaded slopes. Altitude: 0-125 m. Flowering: March, November; fruiting: March, June.

Field notes - Outer bark brown, smooth. Leaves subglossy, green. Pedicels green. Flowers green turning greenish yellow. Monocarps green turning red.

\section{Miliusa traceyi Jessup - Fig. 10; Map 6}

Miliusa traceyi Jessup (1988) 522. - Type: Hyland 10927 (holo BRI n.v.; iso CANB, L, MEL, QRS), Australia, Queensland, Cook District, Massy Creek, November 1980, fl.

Deciduous shrubs, treelets or trees, 3-20 m tall, dbh 7-30 cm. Twigs (sparsely) strigose or tomentose, glabrescent. Petioles $1-4$ by $(0.5-) 0.7-2 \mathrm{~mm}$. Leaves elliptic to ovate, $3-13$ by $2-8 \mathrm{~cm}, 1 / \mathrm{w}$ ratio $(1.4-) 1.7-2.4(-2.7)$, base sometimes unequal, obtuse or rounded, seldom acute or emarginate, apex acute $(-1 \mathrm{~cm})$, lamina above strigose or tomentose, glabrescent, below densely strigose or tomentose, midrib above flat or slightly raised, secondary veins $6-11$ pairs with strong intersecondary veins, angle with midrib $40-60^{\circ}$, angles generally bigger at the base. Cymes in axils of fallen leaves 1(-5)flowered; peduncles $0-9$ by $0.5-1 \mathrm{~mm}$; pedicels $(3-) 9-23(-33)$ by $0.5-1.3 \mathrm{~mm}$; bud scales $1.5-3$ by $1-2.5 \mathrm{~mm}$; bract 1 , triangular, $2-3$ by $1-1.5 \mathrm{~mm}$, apex not recurved; bracteole 1, in material studied no bracteole was found only tuft of hairs indicating the location where it was, caducous. Sepals (broadly) triangular, free, $2-3.3$ by $1.5-2.5$ $\mathrm{mm}$, veins 5 or 6 , not persisting when fruiting. Outer petals boat-shaped, $2-3.5$ by $0.7-1$ $\mathrm{mm}$, apex not curved, veins 5 or 6 . Inner petals narrowly ovate, $0.6-1.2$ by $0.2-0.5 \mathrm{~cm}$, $0.5-1 \mathrm{~mm}$ thick, sac 1-2 by 1-2 mm, apex obtuse to acute, margins recurved, outside sparsely strigose, inside glabrous except margins pubescent, veins 5-6(-8), glandular tissue not visible. Torus elongated hemispherical, $0.7-2$ by $0.7-2 \mathrm{~mm}$. Stamens 8 or 9, 0.7-1 by $0.7-1 \mathrm{~mm}$, connective prolongation obtuse; staminodes 4 or $5,0.4-0.5$ by $0.2-0.5 \mathrm{~mm}$. Carpels $12-14$, round flask-shaped, $0.7-1.3$ by $0.5 \mathrm{~mm}$, glabrous; stigma capitate or globose, $0.2-0.5$ by $0.3 \mathrm{~mm}$, glabrous; ovules 2 , lateral, uniseriate. Monocarps 2-8,(sub)globular to elliptic, $0.6-1$ by $0.6-0.9 \mathrm{~cm}$, apiculation not present; 


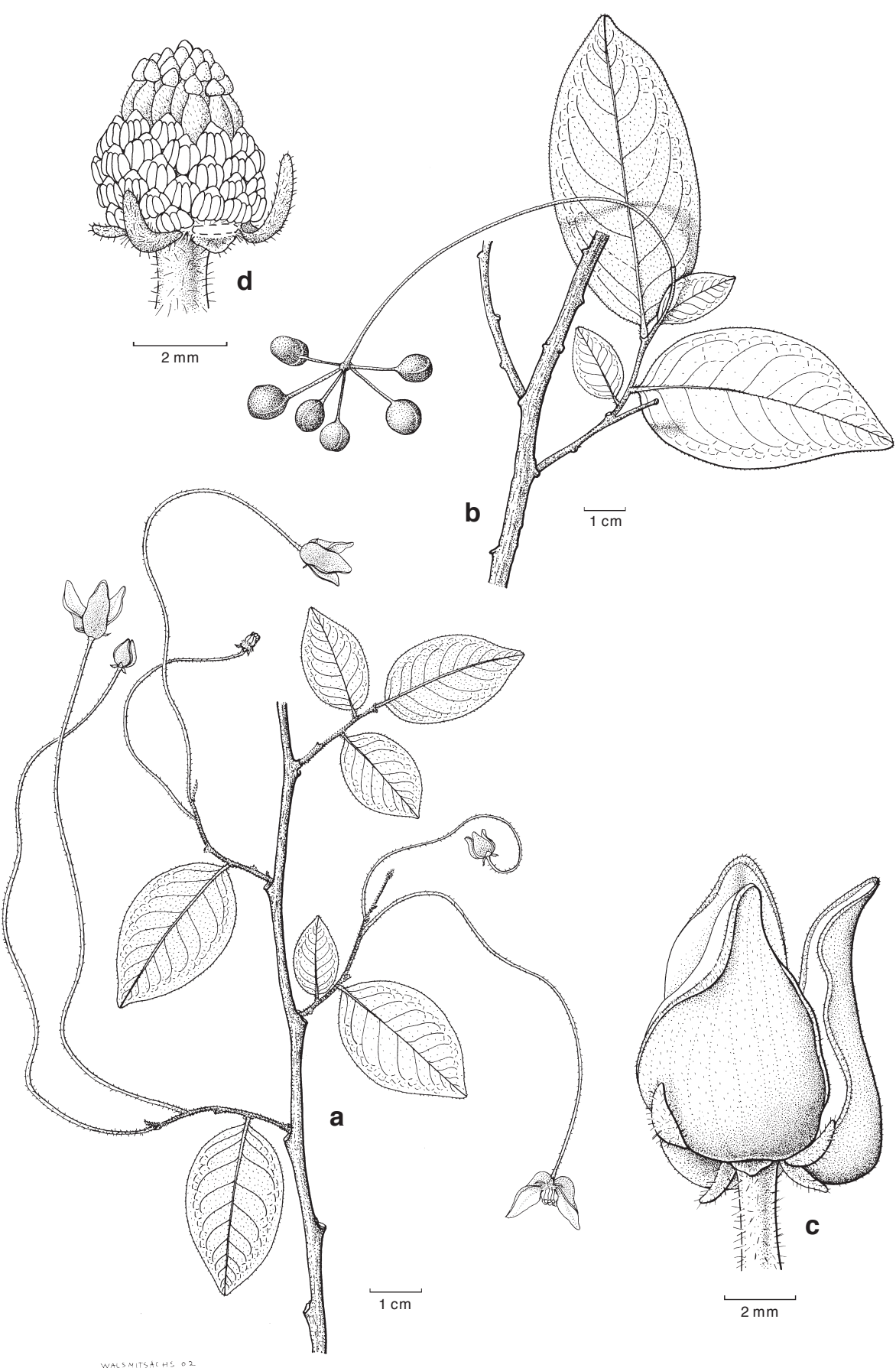

Fig. 11. Miliusa vidalii J. Sinclair. a. Flowering branch; b. fruiting branch; c. flower; d. flower with inner petals removed (a, c, d: FB 6403 (Curran); b: PPI 37658 (Romero \& Fuentes)). 
stipe $2-11$ by $0.7-1 \mathrm{~mm}$. Seed $(s) 1$ or 2 , elliptical or elliptical with one side flattened, $5-6$ by $6-6.5(-9) \mathrm{mm}$, pericarp $0.5-0.8 \mathrm{~mm}$ thick.

Distribution - Northern Australia.

Ecology - Monsoon to semi-deciduous forest, savannah woodland, swamps. Soil: Sandy red soil, rocky outcrop, basalt flow; deep loam, podzol, silty clay, limestone. Location: Along creeks, streams or rivers, between floodplains and low lateric ridges, behind beaches, on ridges. Abundance: Common to dense. Altitude: 0-400 m. Flowering: October and November; fruiting: October to December, March.

Field notes - Outer bark grey to black, fibrous, flaking, hard. Sapwood cream with narrow yellowish stripe. Leaves light green. Sepals yellowish to brown. Outer petals yellowish to brown. Inner petals greenish yellow. Monocarps glossy black.

\section{Miliusa vidalii J. Sinclair - Fig. 11; Map 7}

Miliusa vidalii J. Sinclair (1955) 378. - Saccopetalum longipes S. Vidal (1886) 43 non M. longipes King. - Type: Vidal 15 (lecto K, designated here), Philippines, Luzon, Pr. Bataan, Bagac, fr. Polyalthia pacifica Elmer (1939) 3690, nom. illeg. - Type: Elmer 17357 (holo A; iso BO, L, P), Philippines, Luzon, Prov. Sorsogon, Irosin, Mt. Bulusan, September 1916, fl.

Published without Latin description. No validation could be found.

Deciduous treelets to trees, (3-)12-20 m tall, dbh (4-)15-25 cm. Twigs (densely) pilose, glabrescent. Petioles $1-2(-3)$ by $1-2 \mathrm{~mm}$. Leaves (broadly) elliptic to ovate, $5-17$ by $2.5-6 \mathrm{~cm}, 1 / \mathrm{w}$ ratio (2-)2.4-3.3, base unequal, acute to rounded, slightly emarginate, apex acute to acuminate $(-1.5 \mathrm{~cm})$, lamina (densely) pilose, midrib above flat or slightly sunken, secondary veins 6-11 pairs sometimes with intersecondary veins, angle with midrib $40-60^{\circ}$, angles generally bigger at the base. Cymes extraaxillary or sometimes axillary, 1(-4)-flowered; peduncles $0.2-20$ by $0.7-1.3 \mathrm{~mm}$; pedicels $29-145(-215)$ by $0.5-0.8 \mathrm{~mm}$; bud scales $0.8-2(-3)$ by $1.2-2 \mathrm{~mm}$; bract 1 , triangular, $0.7-1.5$ by $0.5-0.8 \mathrm{~mm}$, apex not recurved; bracteole 1 , triangular, $0.5-1.5$ by $0.3-0.5 \mathrm{~mm}$, apex not recurved, placed at $1 / 4$ to $1 / 3$ from base of pedicel, caducous. Sepals triangular, free, $1.5-2.5$ by $1-1.5 \mathrm{~mm}$, veins 6 or 7 , persisting longer than outer petals. Outer petals boat-shaped, $2-3.5$ by $0.5-0.8 \mathrm{~mm}$, apex not curved, veins not visible. Inner petals ovate, $0.6-1.5$ by $0.4-1 \mathrm{~cm}, 0.5-0.8 \mathrm{~mm}$ thick, sac $2-4$ by 4-6, apex acute, margins not reflexed or recurved, outside (sparsely) strigose, inside glabrous except margins pubescent, veins 9-11, glandular tissue visible. Torus elongated hemispherical, $1.5-2.5$ by $2-3 \mathrm{~mm}$ wide. Stamens $35-55,1-1.3$ by $0.7-1 \mathrm{~mm}$, connective prolongation obtuse; staminodes absent. Carpels 10-18, flask-shaped, 1-2 by $0.5-0.8 \mathrm{~mm}$, scattered strigose; stigma capitate to seldom club-shaped, $0.5-0.8$ by 0.3-0.5 mm, cobwebbed; ovules 8-11, lateral, biseriate. Monocarps 4-16, globose to elliptical or irregular shaped, (0.7-) $1.2-2.5$ by $0.6-1.3 \mathrm{~cm}$, apiculation not present; stipe (4-)10-16(-32) by 1-1.5 mm. Seed (s) (1-) 2-8, elliptical with one or two sides flattened, $6-8$ by $3-5 \mathrm{~mm}$ wide, pericarp $1-1.5 \mathrm{~mm}$ thick.

Distribution - Philippines.

Ecology - Primary and secondary forest. Soil: Loam, clay, limestone. Location: Low undulating country or steep slopes; near banks, beaches or rivers. Altitude: 100300 m. Flowering: January, March to May, August, September; fruiting: Throughout the year. 
Field notes - Outer bark black, fissured. Inner bark pale brown. Petioles green. Leaves yellow green to dark green, smooth. Inner petals purplish. Monocarps (reddish) brown when mature. Tree used for timber.

Vernacular names - Calay, Lanuta, Lapnisan, Takulau (Tagalog).

\section{EXCLUDED SPECIES}

Miliusa bidwilli (Benth.) R.E. Fr. (1955) 42. - Saccopetalum bidwilli Benth. (1863) 53. - Type: Bidwill s.n. (holo K n.v.), Australia, Queensland, Wide Bay. = Fitzalania heteropetala (F. Muell.) F. Muell. (1863) 34. Excluded by Jessup (1988).

Although this species seems to belong to Fitzalania it is most likely a different species within this genus.

Miliusa lucida (Oliv.) Finet \& Gagnep. (1906) 151. - Phaeanthus lucidus Oliv. (1887) pl. 1561. - Type: Curtis 839 (holo K; iso SING) Malaysia, Peninsular Malaysia, Penang, Waterfall, August 1890, fl. = Phaeanthus splendens Miq. (1865) 40.

Synonymised by Mols \& Keßler (2000).

Saccopetalum carnosum Teijsm. \& Binn. (1863) 418. - Type: Cult. Hort. Bog. s.n. (holo BO n.v.), Indonesia, Java. = Trivalvaria carnosa (Teijsm. \& Binn.) Scheff. (1869) 301.

Van Heusden (1997) stated that the latter species is a dubious species and probably represents Trivalvaria macrophylla (Blume) Miq. (1865) 19.

\section{ACKNOWLEDGEMENTS}

Types and other specimens were seen in or borrowed from the following herbaria: AAH, AAU, ABD, B, BKF, BM, BO, BR, BRI, BSD, BSI, C, CAHUP, CAL, CANB, CWG, E, F, G, IBSC, K, KER, L, LAE, LG, M, MEL, MICH, MO, NSW, NY, P, PE, PR, QRS, SAN, SING, U, UC, UKMB, US, W, WU, Z. Directors and curators are gratefully acknowledged. Special thanks to Mr. Priyono (The International MOFEC-Tropenbos-Kalimantan Project) and Mrs. Anita Walsmit Sachs (L) for making the drawings, Mrs. Bertie Joan van Heuven for technical support, Prof. Dr. P. Baas and an anonymous reviewer for valuable comments on the contents and text. Thanks to funding by Tropenbos International, Wageningen, The Netherlands, the junior author (P.J.A.K.) was able to make several field trips to East Kalimantan and to visit Herbarium Bogoriense to select material.

\section{REFERENCES}

Adatia, R.D. \& D.B. Chokshi. 1951. The chromosome numbers in the family Annonaceae. Curr. Sci. 20: 102.

Aleykutty, K.M. \& J.A. Inamdar. 1980. Structure, ontogeny and classification of trichomes in Ranales. Feddes Repert. Spec. Nov. Regni Veg. 91: 95-108.

Ast, S. 1938. Anonacées. In: H. Humbert, Fl. Gén. Indo-Chine, Suppl. 1: 59-123.

Backer, C.A. 2000. Verklarend woordenboek van wetenschappelijke plantennamen. Veen, Amsterdam.

Baillon, H. 1868. Histoire des plantes I: 193-288. Hachette et Cie, Paris.

Beadle, N.C.W. 1981. The vegetation of Australia. Gustav Fischer Verlag, Stuttgart-New York.

Bennett, J.J. 1840. Plantae javanicae rariores: 165-169, pl. 35. Allen \& Co., London.

Bentham, G. 1863. Flora Australiensis. Vol. 1. Reeve \& Co., London. 
Bhargava, A.K. \& C.S. Chauhan. 1968. Antibacterial activity of some essential oils. Indian J. Pharmacy 30: $150-151$.

Chatterjee, D. 1948. New plants from India and Burma. Kew Bull.: 58-60.

Chen, J.H. \& P.T. Li. 1993. Comparative anatomical observation on venation of tribe Saccopetaleae (Annonaceae) in China. Guihaia 13: 26-31.

Chowdhury, K.A. \& S.S. Ghosh. 1958. Indian woods. Their identification, properties and uses. Vol. 1. Manager of Publications Dehra Dun, Dehli.

Chun, W.Y. \& F.C. How. 1958. Contribution to the flora of South China, I. Acta Phytotax. Sin. 7: $1-3$.

Corner, E.J.H. 1949. The Annonaceous seed and its four integuments. New Phytol. 48: 332-364.

Corner, E.J.H. 1976. The seeds of Dicotyledons. Vol. 1. Cambridge University Press, Cambridge.

Craib, W.G. 1923. Six new flowering plants from Siam. J. Nat. Hist. Soc. Siam 6: 43-45.

Craib, W.G. 1924. Contributions to the flora of Siam. Bull. Misc. Inform.: 81-83.

De Candolle, A.L.P.P. 1832. Mémoire sur la famille des Anonacées, et en particular sur les espèces du pays des Birmans. Mém. Soc. Phys. Genève 5: 177-221, pl. 1-5.

Doyle, J.A., P.C. Bygrave \& A. le Thomas. 2000. Implications of molecular data for pollen evolution in Annonaceae. In: M.M. Harley, C.M. Morton \& S. Blackmore (eds.), Pollen and spores: Morphology and biology: 259-284. Royal Botanical Gardens, Kew.

Doyle, J.A. \& A. le Thomas. 1994. Cladistic analysis and pollen evolution in Annonaceae. Acta Bot. Gallica 141: 149-170.

Doyle, J.A. \& A. le Thomas. 1996. Phylogenetic analysis and character evolution in Annonaceae. Adansonia 18: 279-334.

Doyle, J.A. \& A. le Thomas. 1997. Significance of palynology for phylogeny of Annonaceae: Experiments with removal of pollen characters. Pl. Syst. Evol. 206: 133-159.

Drummond, J.R. 1920. Miliusa and Saccopetalum (Family Annonaceae). J. Indian Bot. 1: 162168.

Elmer, A.D.E. 1913. New Annonaceae. Leafl. Philipp. Bot. 5: 1705-1750.

Elmer, A.D.E. 1939. Miscellaneous new species. Leafl. Philipp. Bot. 10: 3684-3692.

Finet, A. \& F. Gagnepain. 1906. Contribution à l'étude de la flore de l'Asie orientale. Bull. Soc. Bot. France 53, Mémoires Vol. 4 (2e partie): 55-170.

Fischer, C.E.C. 1926. Contributions to the flora of Burma: I. Bull. Misc. Inform.: 448-455.

Foxworthy, F.W. 1909. Indo-Malayan woods. Philipp. J. Sci., Bot. 4: 409-592.

Fries, R.E. 1955. Verstreute Beobachtungen hinsichtlich der Familie Annonaceae. Ark. Bot. n.s. 3: $35-42$.

Fries, R.E. 1959. Annonaceae. In: A. Engler \& K. Prantl (eds.), Die natürlichen Pflanzenfamilien, ed. 2, 17a, IIB: 1-171. Duncker \& Humblot, Berlin.

Gottsberger, G. 1999. Pollination and evolution in neotropical Annonaceae. Pl. Spec. Biol. 14: $143-152$.

Greshoff, M. 1898. Tweede verslag van het onderzoek naar de plantenstoffen van Nederlandsch-Indië. Meded. Lands Plantentuin 25.

Hallé, F. \& R.A.A. Oldeman. 1970. Essai sur l'architecture et la dynamique de croissance des Arbres tropicaux. Monographie de Botanique et de Biologie Végétable 6: 1-178.

Harrigan, G.G., A.A.L. Gunatilaka, D.G.I. Kingston, G.W. Chan \& R.K. Johnson. 1994. Isolation of bioactive and other oxoarphine alkaloids from two Annonaceous plants, Xylopia aethiopica and Miliusa cf. banacea. J. Nat. Prod. 57: 68-73.

Hewson, H.J. 1988. Plant indumentum. A handbook of terminology. Australian Flora and Fauna Series 9.

Hooker, J.D. \& T. Thomson. 1855. Flora Indica I: 86-153. Pamplin, London.

Huber, H. 1985. Annonaceae. In: M.D. Dassanayake \& F.R. Fosberg (eds.), A revised handbook to the Flora of Ceylon 5: 1-75. Amarind Publishing Co. Pvt. Ltd., New Delhi.

Jessup. L.W. 1986. New combinations in Australian Annonaceae. Austrobaileya 2: 227.

Jessup, L.W. 1988. The genus Miliusa Leschen. ex A.DC. (Annonaceae) in Australia. Austrobaileya 2: $517-523$.

Johnson, D.M. In prep. Phylogenetic significance of spiral and distichous architecture in the Annonaceae. 
Jovet-Ast, S. 1942. Recherches sur les Annonacées d'Indochine. Anatomie foliaire. Répartition géographique. Mém. Mus. Natl. Hist. Nat. 16: 125-308.

Jumana, S., C.H. Hasan \& M.A. Rashid. 2000. Alkaloids from the stem bark of Miliusa velutina. Biochem. Syst. \& Ecol. 28: 483-485.

Kar, A. \& S.R. Jain. 1971. Investigations on the antibacterial activity of some Indian indigenous aromatic plants. Flav. Industr. 2: 111-113.

Keßler, P.J.A. 1993. Annonaceae. In: K. Kubitzki, J.G. Rohwer \& V. Bittrich (eds.), The families and genera of vascular plants. 2: 93-129. Springer Verlag, Berlin.

Keßler, P.J.A. 1998. Miliusa. In: M.S.M. Sosef, L.T. Hong \& S. Prawirohatmodjo (eds.), Timber trees: Lesser-known timbers. ProseA 5, 3: 381-382. Backhuys Publishers, Leiden.

King, G. 1893. Materials for a flora of the Malay Peninsula. J. Asiat. Soc. Bengal, Pt. 2, Nat. Hist. 61: 1-130.

Klucking, E.P. 1986. Leaf venation patterns, 1. Annonaceae. J. Cramer, Berlin-Stuttgart.

Kostermans, A.J.G.H. 1952. Notes on New Guinea plants - IV. Saccopetalum koolsii Kostermans sp. nov. Reinwardtia 1: 459-461.

Kurz, W.S. 1870. On some new or imperfectly known Indian plants. J. Asiat. Soc. Bengal, Pt 2, Nat. Hist. 39: 61-91.

Kurz, W.S. 1874. Contributions towards a knowledge of the Burmese flora. J. Asiat. Soc. Bengal, Pt 2, Nat. Hist. 43: 39-141.

Le Thomas, A. 1980. Ultrastructural characters of the pollen grains of African Annonaceae and their significance for the phylogeny of primitive angiosperms I. Pollen \& Spores 22: 267-342.

Le Thomas, A. 1981 Ultrastructural characters of the pollen grains of African Annonaceae and their significance for the phylogeny of primitive angiosperms II. Pollen \& Spores 23: 5-36.

Le Thomas, A., W. Morawetz \& M. Waha. 1986. Pollen of palaeo- and neotropical Annonaceae: Definition of the aperture by morphological and functional characters. In: S. Blackmore \& I.K. Ferguson (eds.), Pollen and spores: Form and function: 375-388. Linnean Society Symposium Series 12. Academic Press, London.

Leonardía, A.A.P. \& P.J.A. Keßler. 2001. Additions to Orophea subgenus Sphaerocarpon (Annonaceae): Revision and transfer of Mezzettiopsis. Blumea 46: 141-163.

Leopold, E.B. 1969. Miocene pollen and spore flora of Eniwetok Atoll, Marshall Islands. Profess. Pap. U.S. Geol. Surv. 260-II: 1133-1185.

Li, P.T. 1993. Novelties in Annonaceae from Asia. Guihaia 13: 311-315.

Lindley, J. 1836. A natural system of botany. Longman, Reese, Orne, Brown, Green \& Longmans, London.

Lindsay, B.Y., K. Waliwararra, F. Miljat, H. Kuwarda, R. Pirak, A. Muyung, E. Pambany, J. Marruridj, P. Marrfurra \& G. Wightman. 2001. Malakmalak and matngala. Plants and animals: Aboriginal flora and fauna knowledge from the Daly River area, northern Australia. Northern Territory Botanical Bulletin 26: 1-125.

Löve, A. (ed.) 1979. IOPB Chromosome number reports LXIV. Taxon 28: 391-408.

Löve, A. (ed.) 1980. IOPB Chromosome number reports LXVI. Taxon 29: 163-169.

Löve, A. (ed.) 1982. IOPB Chromosome number reports LXXVI. Taxon 31: 574-598.

MacKinnon, K., G. Hatta, H. Halim \& A. Mangalik. 1997. The ecology of Kalimantan. The Ecology of Indonesia Series Vol. 3. Periplus Editions (HK) Ltd., Singapore.

Meisner, C.F. 1837. Plantarum vascularium genera 1. Libreria Weidmannia, Leipzig.

Meisner, C.F. 1839. Plantarum vascularium genera 2. Libreria Weidmannia, Leipzig.

Menon, M.K. \& A. Kar. 1970. Analgesic effect of the essential oil of Miliusa tomentosa (Roxb.) J. Sinclair. Indian J. Exp. Biol. 8: 151-152.

Merrill, E.D. \& W.Y. Chun. 1935. Additions to our knowledge of the Hainan Flora, III. Sunyatsenia 2: $223-232$.

Miquel, F.A.W. 1858. Flora van Nederlandsch-Indië 1, 2: 20-52. Van der Post, Amsterdam.

Miquel, F.A.W. 1865. Annonaceae Archipelagi Indici. Ann. Mus. Bot. Lugd.-Bat. 2: 1-45.

Moll, J.W. \& H.H. Janssonius. 1906. Mikrographie des Holzes der auf Java vorkommenden Baumarten, Vol. 1. Brill, Leiden. 
Mols, J.B., B. Gravendeel, L.W. Chatrou, M.D. Pirie, P.C. Bygrave, M.W. Chase \& P.J.A. Keßler. In prep. Identifying clades in Asian Annonaceae: Monophyletic genera in the polyphyletic Miliuseae.

Mols, J.B. \& P.J.A. Keßler. 2000. Revision of the genus Phaeanthus (Annonaceae). Blumea 45: 205-233.

Mols, J.B. \& P.J.A. Keßler. In press. Studies in the Miliuseae. Review of the taxonomic history of a polyphyletic 'tribe'. Telopea 10.

Morawetz, W. 1986. Remarks on karyological differentiation patterns in tropical woody plants. Pl. Syst. Evol. 152: 49-100.

Morawetz, W. 1988. Karyosystematics and evolution of Australian Annonaceae as compared with Eupomatiaceae, Himantandraceae, and Austrobaileyaceae. Pl. Syst. Evol. 159: 49-79.

Mueller, F.J.H. 1863. Fragmenta phytographiae Australiae 4. Ex officina Joannis Ferres, Melbourne.

Mueller, F.J.H. 1874. Fragmenta phytographiae Australiae 8. Ex officina Joannis Ferres, Melbourne.

Norman, E.M., K. Rice \& S. Cochran. 1992. Reproductive biology of Asimina parviflora (Annonaceae). Bull. Torrey Bot. Club 119: 1-5.

Okada, H. 1990. Reproductive biology of Polyalthia littoralis (Annonaceae). Pl. Syst. Evol. 170: 237-245.

Okada, H. \& K. Ueda. 1984. Cytotaxonomical studies on Asian Annonaceae. Pl. Syst. Evol. 144: $165-177$.

Oliver, D. 1887. Phaeanthus lucida. In: J.D. Hooker (ed.), Hooker's Icones Plantarum, ser. 3: 1561.

Panigrahi, G. \& S.C. Mishra. 1984. Miliusa globosa, comb. nov. for M. roxburghiana (Annonaceae). Taxon 33: 713-714.

Parkinson, C.E. 1923. A forestflora of the Andaman Islands. Government Central Press, Simla.

Patel, R.J. 1971. Epidermal structure and development of stomata in some Annonaceae. Ann. Bot. 35: 1205-1212.

Pearson, R.S. \& H.P. Brown. 1932. Commercial timbers of India, Vol. 1. Govt. of India, Central Publication Branch, Calcutta.

Periasamy, K. \& B.G.L. Swamy. 1959. Studies in the Annonaceae I. Microsporogenesis in Cananga odorata and Miliusa wightiana. Phytomorphology 9: 251-263.

Periasamy, K. \& B.G.L. Swamy. 1961. Studies in the Annonaceae II. The development of ovule and seed in Cananga odorata and Miliusa wightiana. J. Indian Bot. Soc. 40: 206-216.

Pierre, L. 1881. Flore forestière de la Cochinchine. Octave Doin, Paris.

Qiu, Y.L., J. Lee, F. Bernasconi-Quadroni, D.E. Soltis, P.S. Soltis, M. Zanis, E.A. Zimmer, Z. Chen, V. Savolainen \& M.W. Chase. 2000. Phylogeny of basal angiosperms: Analysis of five genes from three genomes. Int. J. Plant Sci. 161, Suppl. 6: 3-27.

Ridder, T.B. 1995. Rainfall in New Guinea (Irian Jaya). KNMI-publicatie 183-1. KNMI, De Bilt.

Ridley, H.N. 1910. New or rare Malayan plants. Series V. J. Straits Branch Roy. Asiat. Soc. 54: 11-13.

Ridley, H.N. 1911. The flora of lower Siam. J. Straits Branch Roy. Asiat. Soc. 59: 63-66.

Sastri, R.L.N. 1957. The vascularization of the ovules in Saccopetalum tomentosum. Curr. Sci. 26: 183.

Sastri, R.L.N. 1969. Comparative morphology and phylogeny of the Ranales. Biol. Rev. Cambridge Philos. Soc. 44: 291-319.

Scheffer, R.H.C.C. 1869. In: J.K. Haßkarl, Observationes phytographicae auctore R.H.C.C. Scheffer. Flora 52: 299-304.

Shah, G.L. \& G.V. Gopal. 1982. An ethnobotanical profile of the Dangies. J. Econ. Taxon. Bot. 3: $355-364$.

Sidiyasa, K. 1998. Miliusa (character list). In: M.S.M. Sosef,L.T. Hong \& S. Prawirohatmodjo (eds.), Timber trees: Lesser-known timbers. Prosea 5, 3: 617. Backhuys Publishers, Leiden.

Sinclair, J. 1955. A revision of the Malayan Annonaceae. Gard. Bull. Straits Settlem. 14: 149-516. Smith, A.C. 1981. Flora Vitiensis Nova Vol. 2. Pacific Tropical Botanical Garden, Lawai. 
Soltis, D.E., P.S. Soltis, M.W. Chase, M.E. Mort, D.C. Albach, M. Zanis, V. Savolainen, W.H. Hahn, S.B. Hoot, M.F. Fay, M. Axtell, S.M. Swensen, L.M. Prince, W.J. Kress, K.C. Nixon \& J.S. Farris. 2000. Angiosperm phylogeny inferred from $18 \mathrm{~S}$ rRNA, rbcL and atpB sequences. Bot. J. Linn. Soc. 133: 381-461.

Teijsmann, J.E. \& S. Binnendijk. 1863. Plantae novae in horto bogoriensi cultae. Tijdschr. Ned.Indië 25: 418-420.

Tsiang, Y. \& P.T. Li. 1964. Diagnoses of new Annonaceous plants from Hainan. Acta Phytotax. Sin. 9: $374-382$.

Van Heusden,E.C.H. 1997. Revision of the southeast Asian genus Trivalvaria (Annonaceae). Nordic J. Bot. 17: 169-180.

Van Setten, A.K. \& J. Koek-Noorman. 1992. Fruits and seeds of Annonaceae: morphology and its significance for identification. Biblioth. Bot. 142.

Van Steenis, C.G.G.J. 1979. Plant-geography of East Malesia. Bot. J. Linn. Soc. 79: 97-178.

Vidal y Soler, S. 1886. Revisíon de plantas vasculares filipinas. M. Perez Hijo, Manila.

Waha, M. \& M. Hesse. 1988. Aperture types within Sapranthus and Polyalthia (Annonaceae). Pl. Syst. Evol. 161: 135-146.

Waha, M. \& W. Morawetz. 1988. Pollen evolution and systematics in Annonaceae with special reference to the disulcate Australian endemic genera. Pl. Syst. Evol. 161: 1-12.

Walker, J.W. 1971. Pollen morphology, phytogeography and phylogeny of the Annonaceae. Contr. Gray Herb. 202: 1-130.

Walker, J.W. 1972. Chromosome number, phylogeny, phytogeography of the Annonaceae and their bearing on the (original) basic chromosome number of Angiosperms. Taxon 21: 57-65.

Wallich, N. 1832. A numerical list of dried plants in the East India Company's Museum. Handwritten.

Weberling, F. 1981. Morphologie der Blüten und der Blütenstände. Verlag Eugen Ulmer, Stuttgart. Wyatt-Smith, J. 1979. Training and research in multiple-use forest management. The Philippines. Management research of Philippine Dipterocarp forest. FAO, Rome.

Yoganarasimhan, S.N., V.S. Togunashi, K.R. Keshavamurthy \& Govindaiah. 1982. Medico Botany in Tumkur district, Karnataka. J. Econ. Taxon. Bot. 3: 391-406.

Yunupinu, B., L. Yunupinu-Marika, D. Marika, B. Marika, B. Marika, R. Marika \& G. Wightman. 1995. Rirratjunu ethnobotany: Aboriginal plant use from Yirrkala, Arnhem Land, Australia. Northern Territory Bot. Bull. 21: 57.

\section{IDENTIFICATION LIST}

The numbers behind the collections refer to the species numbers as given in the key and descriptions above. When the number of the collection is not available or unknown, the collection is not mentioned in this list. The collections from institutions can be found under the abbreviation of the institutions (the collectors are mentioned between brackets).
1. M. amplexicaulis
2. M. brahei
3. M. horsfieldii
4. M. koolsii
5. M. longipes
6. M. macropoda
7. M. novoguineensis
8. M. parviflora
9. M. traceyi
10. M. vidalii

Agung 5: 3 - Ahern's Collector 96: 10 - Akin SA 2596: 6 - Alfred 211: 3 - Allen 5210/19: 2 - Ambriansyah \& Arifin AA 272: 6; B 1515: 6 - Anonymous (Koorders?) 114r: 3.

Backer 17620: 3; 19635: 3 - Batianoff 9207196: 2 - bb Cel/I-96 (Boschproefstation): 3; 2535

(Pieters): 3; 5853 (Boschproefstation): 3; 5863 (Boschproefstation): 3; 13821 (Mohar): 3; 21343 (Waturandang): 3; 21344 (Waturandang): 3; 28920 (Neth. Ind. For. Services): 4; 29749 (Asda \& Anta): 3; 29939 (Bloembergen): 3; 33913: (Tangkilisan): 3 - Becking 149: 3 - Beumée 3686: 3; 3741: 3 - Boschwezen K 16: 3; IV: 3 - BS 1013: (Ramos): 10; 15577 (Kienholz): 10; 42172 (Ramos): 10; 84862 (Ramos \& Edaño): 10 - BSI 2530 (Chakraborty): 3 - Budworth 944: 9 
- BW 4503 (Lasschuit): 4; 4567 (Lasschuit): 4; 7247 (Koster): 7; 7506 (Versteegh): 4; 7819 (Schram): 7; 7847 (Schram): 7; 7862 (Schram): 7; 7896 (Schram): 7; 8167 (Van der Rijdt): 4; 8555 (Vink): 4; 11641 (Moll): 4; 12407 (Schram): 4; 13267 (Schram): 4 - Byrnes 1203: 9; 2088: 2. Cameron 2461: 9; 20185: 9; 20328: 9; 20394: 9 - Carr 16518: 4 - Champion 565: 2 - Chen 320: 3 - Clarke WCC 1061: 9; WCC 1068: 9; WCC 1105: 9 - Clarkson \& McDonald 6769: 9 - Cousins 158: 2 - Cult. in Hort. Bog. 17704: 3; Kiemplanten 3213: 3; Kiemplanten 3220: 3 - Cuming 1198: 10 - Curtis 3205: 1.

Dalliston CC 302: 9 - De Wilde \& De Wilde-Duyfjes 18488: 5; 18867: 5 - De Wit 8: 3 - Den Berger 354: 3 - Dockrill 544: 3; 854: 9 - Dransfield 6325: 6 - Dunlop 3632: 2.

Elmer 12677: 3; 17357: 10 - Endert 5168: 6; 5189: 6.

FB 6403 (Curran): 10; 7105 (Klemme): 10; 20987 (Villamil): 10; 23854 (Paraiso): 10; 25475 (Paraiso): 10 - Fell DF 1534: 2; DF 2778: 2 - Fell \& Basini 2452:3 - Fell \& Daunt DGF 4287: 2 - Fell \& Jensen DF 2475: 3 - Fell \& Stanton DGF 2786: 3; DGF 4220: 2 - Forbes 1393: 5; 1771: 5 - Forest Department Hainan 90302: 3 - Forster \& Tucker PIF 5619: 9.

Geesink et al. 6952: 3 - Gray 4977: 2; 4978: 2 - Gusdorf 279: 3; 281: 3.

Hardial 587: 5 - Holmes 44: 2 - Holtze 325: 9; 392: 2; 654: 2; 7758: 2 - How 70951: 3; 71794: 3; 72328: 3 - Hyland RFK 2536: 9; RFK 2544 3; 6408: 3; 6563: 3; 6640: 3; 7588: 9; 10672: 3; 10811: 3 ; 10852: 3; 10908: 9, 10927: 9, 14380: 9, 15125: 9 .

Iboet 25: 5 - Irvine 238: 3 - Ismail \& Arifin BRF 1684: 6.

Jacobs 4785: 3 - Jamaat 16501: 5 - Jaman 4899: 5 - Jensen 793: 3 - Jessup 551: 2; 616: 3; 622: 3; 644: 3; 656: 3; 773: 3; 774: 9; 820: 9; 822: 9; 834: 9; 835: 9 - Jones 2038: 2; 3535: 2.

Kalkman 3723: 3 - Kalshoven 60: 3; 77: 3; 95: 3 - Kanis 2134: 2 - Keith 457: 1 - Keneally 8748: 2 - Keneally \& Hyland 10354: 2 - KEP/FRI 6074 (Ng): 5; 14790 (Suppiah): 5; 16305 (Kochummen): 3; 19940 (Chan): 5; 39469 (Chung, Mat Asri, Ayan \& Apuk): 5 - Kerr 6012: 3; 14828: 5; 14830: 1; 15041: 5; 17266: 3; 17889: 3; 18520: 1; 190980: 3; 20910: 3 - Keßler \& Arbainsyah B 1364: 6 - King 2373: 1; 5734: 5; 7162: 5; 7352: 5; 7437: 5 - KL 546 (Gadoh anak Umbai \& Millard): 5; 1465 (Gadoh): 5; 2053 (Gadoh anak Umbai): 5 - Koorders 535: 3; 566: $3 ; 569: 3 ; 570: 3 ; 598: 3 ; 599: 3 ; 600: 3 ; 601: 3 ; 602: 3 ; 603: 3 ; 604: 3 ; 605: 3 ; 624: 3 ; 625$ : 3 ; 664: 3 ; 667: 3 ; 12732: 3; 13446: 3; 13743: 3; 15989: 3; 25191: 3; 25203: 3; 25395: 3; 28197: 3; 28847: 3 ; 28851: 3 ; 30624: 3 ; 30625: 3 ; 31806: 3 ; 34078: 3 ; 36493: 3 ; 37215: 3; 42322: 3 ; 42350: 3; 42389: 3 - Kostermans 62: 4; 227: 4; 430: 4; 485: 4; 5308: 6; 13973: 6; 19012: 3; 21219: 6 - Kostermans \& Kuswata 55: 3.

Lam 2582: 3 - Larsen et al. 44047: 1 - Latiff 3950: 5 - Leach \& Dunlop 1603: 9 - Li \& Cheng 44: 3 - Loher 52: 10; 5154: 10; 12769: 10; 13255: 10 - Lyons 58: 2.

Maradjo 165: 5 - Maxwell 76-388: 3; 85-866: 5; 86-418: 8; 87-565: 1 - McDonald, Fell \& Stanton 442: 2 - Meijer 10755: 3 - Merrill 1728: 10; 2965: 10 - Mols JM 4 (Cult.): 3; JM 12 (Cult.): 3 - Mueller 29: 9; 53: 2.

NGF 24845 (Womersley): 7; 28031 (Henty): 4 - Nitrasirirak 238: 5 - Niyomdham et al. 2160: 1. Okada 3202 (Cult.): 3; 3374 (Cult.): 3; 3392 (Cult.): 3.

Palisoc CLP 1630: 10 - Parker 509: 9 - Parkinson 545: 3; 1694: 3 - Partodimedjo JA 1579: 3 - Phusomsaeng 436: 5 - PNH 6871 (Sulit): 10; 17156 (Sulit): 10; 22887 (Sulit): 10; 22890 (Sulit): 10 - PPI 17211 (Reynoso et al.): 10; 17241 (Reynoso et al.): 10; 24488 (Reynoso \& Majaducon): 10; 37658 (Romero \& Fuentes): 10.

Rankin 1515: 2; 1517: 2; 1675: 9 - Razali RJ 659: 8 - Ridley 4709: 5, 8450: 5; 14646: 1; 15239: 8; 15340: 8 - Russell-Smith 868: 9 - Russell-Smith \& Lucas 6445: 2; 5971: 2; 6502: 9.

SAN 26901 (Chai): 6; 34004 (Aban): 6; 36955 (Aban): 6; 65893 (Talip): 6; 68721 (Fedilis; Sigin et al.): 6; 73566 (Aban \& Termiji): 6; 91635 (Aban \& Dewol): 6; 93145 (Dewol): 6; 93693 (Dewol): 6; 96410 (Matin \& Sigin): 6; 99213 (Aban): 6; 108378 (Argent et al.): 6; 109978 (Mantor): 6; 114519 (Madani et al.): 6; 116909 (Joseph \& Lideh): 6; 117006 (Mansus \& Amin): 6; 118064 (Tokilip): 6; 123726 (George et al.): 6- Sankowsky 227: 3; 701: 2; 1643: 9 - Sankowsky \& Sankowsky 226: 3; 253: 9; 275: 9; 588: 3; 749: 2- Schulz 148: 2 - Scortechini 710: 5 - SF 3972 (Haniff \& Nur): $1 ; 10039$ (Sinclair): 3; 22367 (Henderson): 3; 23841 (Henderson): 5; 24544 (Henderson): 3; 25020 (Henderson): 5; 25038 (Henderson): 5; 28949 (Henderson): 8; 35049 (Kiah): 5; 35363 (Kiah): 1; 41008 (Chew Wee Lek): 5 - Shah \& Noor MS 2031: 5 - Shah \& Samsuri MS 1719: 
5 - Sidiyasa et al. B 1244: 6- Smith 684: 5; 691: 5; 14369: 3 - Smythe MP 22.3: 9; OP 19.2:

9 - Snau 297: 5; 1068: 5 - Soejarto, Fernando \& Majaducon 9129: 3 - Soejarto, Fernando \&

Sagcal 7768: 10 - Stocker 1629: 3 - Stone 6963: 1; 14280: 8 - Suhanda \& Ilham 17: 4.

Teijsmann 13576: 3 - Tracey 13940: 2; 14040: 9; 14042: 2; 14056: 2; 14247: 9; 14249: 9.

Unesco 18: 3 - Universiti Kebangsaan Malaysia Group B 21: 5 - Unwin 631: 3.

Van Balgooy 5140 (Cult.): 3 - Van Balgooy \& Van Setten 5649 (Cult.): 3 - Van Steenis 2385: 5

— Vidal 15: 10; 15bis: 10; 1112: 10; 2049: 10.

Wasijat Ja 6190: 3 - Webb \& Tracey 7037: 9; 7755: 3; 7788: 3; 7897: 9; 7965: 2; 8029: 9; 8034:

9; 8317: 3; 8729: 3; 8810: 3; 9018: 3; 9380: 3; 9970: 9; 11049: 3; 11884: 2; 12058: 3; 12193: 9;

12199: 9; 12475: 2; 12496: 9; 12497: 9; 12498: 9; 12686: 3; 13347: 3; 13361: 3 ; 13362: 3; 13364 :

3; 13365: 3; 13366: 3 - White 1202: 3 - Whitford 1315: 10 - Wightman 1668: 2; 1674: 2

- Wirawan 409: 3 - Wiriadinata \& Maskuri 551: 5 - Wood A 4844: 6.

Yoshida 1944: 5 - Young 437: 2.

\section{INDEX TO SCIENTIFIC NAMES}

The accepted names are in roman type and the synonyms in italics. The 'excluded species' are indicated by excl. The new taxon is printed in bold. The numbers behind the names refer to the species in this revision.

\author{
Alphonsea mollis Merr. \& Chun 3 \\ prolifica Chun \& F.C. How 3 \\ Fitzalania heteropetala (F. Muell.) \\ F. Muell. excl. \\ Hyalostemma Wall. [p. 432] \\ Miliusa Lesch. ex A.DC. [p. 422, 432] \\ amplexicaulis Ridl. 1 \\ arborea (Elmer) J. Sinclair 3 \\ bidwilli (Benth.) R.E. Fr. excl. \\ brahei (F. Muell.) Jessup 2 \\ horsfieldii (Benn.) Pierre 3 \\ koolsii (Kosterm.) J. Sinclair 4 \\ lineata (Craib) Ast 3 \\ longipes King 5 \\ lucida (Oliv.) Finet \& Gagnep. excl. \\ macropoda Miq. 6 \\ novoguineensis Mols \& Keßler 7 \\ parviflora Ridl. 8 \\ prolifica (Chun \& F.C. How) P.T. Li 3 \\ smithiae Craib 5 \\ tectona C.E. Parkinson 3
}

\author{
(Miliusa) \\ traceyi Jessup 9 \\ unguiculata (C.E.C. Fisch.) J. Sinclair 3 \\ vidalii J. Sinclair 10 \\ Phaeanthus lucidus Oliv. excl. \\ splendens Miq. excl. \\ Polyalthia pacifica Elmer 10 \\ Saccopetalum Benn. [p. 432] \\ arboreum Elmer 3 \\ bidwilli Benth. excl. \\ brahei F. Muell. 2 \\ carnosum Teijsm. \& Binn. excl. \\ horsfieldii Benn. 3 \\ koolsii Kosterm. 4 \\ lineatum Craib 3 \\ longipes $\mathrm{S}$. Vidal 10 \\ prolificum (Chun \& F.C. How) Tsiang 3 \\ tectonum (C.E. Parkinson) Chatterjee 3 \\ unguiculatum C.E.C. Fisch. 3 \\ Trivalvaria carnosa (Teijsm. \& Binn.) \\ Scheff. excl.
}

